\title{
Role of Divalent Cations in HIV-1 Replication and Pathogenicity
}

\author{
Nabab Khan ${ }^{\oplus}$, Xuesong Chen and Jonathan D. Geiger *(D) \\ Department of Biomedical Sciences, University of North Dakota School of Medicine and Health Sciences, \\ Grand Forks, ND 58203, USA; nabab.khan@und.edu (N.K.); xuesong.chen@und.edu (X.C.) \\ * Correspondence: jonathan.geiger@und.edu; Tel.: +1-(701)-777-2183; Fax: +1-(701)-777-0387
}

Received: 31 March 2020; Accepted: 18 April 2020; Published: 21 April 2020

\begin{abstract}
Divalent cations are essential for life and are fundamentally important coordinators of cellular metabolism, cell growth, host-pathogen interactions, and cell death. Specifically, for human immunodeficiency virus type-1 (HIV-1), divalent cations are required for interactions between viral and host factors that govern HIV-1 replication and pathogenicity. Homeostatic regulation of divalent cations' levels and actions appear to change as HIV-1 infection progresses and as changes occur between HIV-1 and the host. In people living with HIV-1, dietary supplementation with divalent cations may increase HIV-1 replication, whereas cation chelation may suppress HIV-1 replication and decrease disease progression. Here, we review literature on the roles of zinc $\left(\mathrm{Zn}^{2+}\right)$, iron $\left(\mathrm{Fe}^{2+}\right)$, manganese $\left(\mathrm{Mn}^{2+}\right)$, magnesium $\left(\mathrm{Mg}^{2+}\right)$, selenium $\left(\mathrm{Se}^{2+}\right)$, and copper $\left(\mathrm{Cu}^{2+}\right)$ in HIV-1 replication and pathogenicity, as well as evidence that divalent cation levels and actions may be targeted therapeutically in people living with HIV-1.
\end{abstract}

Keywords: human immunodeficiency virus type-1; transactivator of transcription; HIV-1 associated neurocognitive disorders; divalent cations; endolysosomes

\section{Introduction}

Divalent cations help regulate vital cellular functions and accumulation of divalent cations has been implicated in healthy aging as well as the pathogenesis of various neurodegenerative diseases and cancer [1-4]. Underlying such physiological regulatory events and pathological conditions are divalent cation-dependent metalloproteins and metalloenzymes [5-9]. These proteins are required for critical cellular functions, including signal transduction [10], cell division [11], cell excretions [12], gene transcription [13], immune response and regulation [14,15], and cell adhesion [16,17]. Therefore, it is not surprising that multiple receptors and ligands exist in eukaryotic cells that are capable of sorting, transporting, and delivering divalent cations [18-30].

Additionally, divalent cations play prominent roles in host-pathogen interactions [31-33]. And, as above, homeostatic regulation of divalent cation levels is important, because they can affect microbial infection $[34,35]$. This is certainly true for human immunodeficiency virus type-1 (HIV-1), because levels of divalent cations change during HIV-1 infection. However, it is not yet clear if the changes in divalent cation concentrations construe a defense strategy of the host or the virus [36-41]. Thus, it is important to focus additional attention on the involvement of divalent cations in HIV-1 replication and infection. 


\section{HIV-1 Infection and Replication}

More than 40 million people are currently living with HIV-1, the causative agent of acquired immunodeficiency syndrome (AIDS). Early in the HIV-1/AIDS pandemic, the high rate of mortality in people living with HIV-1 (PLWH) was due mainly to opportunistic infections. However, with the use of modern anti-retroviral therapeutic (ART) strategies, PLWH are now living almost full life spans [42]. Hence, HIV-1 has become a chronic managed disease.

HIV-1 is a single-stranded RNA lentivirus whose genome is encoded by nine different genes; each gene is transcribed into specific proteins. HIV-1 enters cells by first fusing its viral coat protein gp120 with host receptor proteins, especially CD4 (Figure 1) [43]. Before integration, non-integrated DNA generates all three classes of viral transcripts; the multiply spliced, single spliced, and full-length transcripts. The multiply spliced, early transcripts (tat, rev and nef) generate early proteins; Tat, Rev, and Nef. These early viral proteins promote virus replication [44]. With the active transcription process, new transcripts are then produced and translated; these include mRNAs for the Gag-Pol polyprotein, and the virion's genomic RNA (Figure 1) [44-46]. During transcription as well as post-transcription, new virus particles are assembled in and released from infected cells to initiate bystander cell infection [47].

HIV-1 Tat is essential for initiating, elongating, and terminating HIV-1 replication, especially early in the infection cycle [48]. The initiation and elongation of transcription is further aided by the ability of HIV-1 Tat to enhance the association of multiple host factors at the HIV-1 LTR promoter site [49-52]. HIV-1 Tat is a virotoxin that is actively secreted from infected cells [53-55] and it continues to be implicated in the pathogenesis of HIV-1-associated neurocognitive disorders (HAND) [56-59]. Because of its importance as a regulator of HIV-1 replication and the pathogenesis of HAND [60,61], this review will focus mainly on HIV-1 Tat, but other HIV-1 viral factors will be discussed as well.

\section{Structural and Functional Domains of HIV-1 Tat}

Post-infection, HIV-1 Tat is produced from the primary transcript of HIV-1. HIV-1 Tat is composed of 86 to 101 amino acids and six distinct domains have been characterized according to their constituent amino acids and their functionality [62-64]. Domain one contains proline-rich acidic amino acids, which is referred to as N-terminal domain (1-21 amino acids). The second domain (21-37 amino acids) has seven cysteine residues (Cys22, Cys25, Cys27, Cys30, Cys31, Cys34, and Cys37), the sites at which disulfide scaffolds are mainly formed under the influence of divalent cations [65,66]. $\mathrm{Zn}^{2+}$ appears especially important at these sites, because it facilitates the formation of bridges between Tat and CyclinT1; the result is advanced HIV-1 transcription [67]. Genetic variations in the cysteine-rich domain decrease associations between cellular proteins and transcription factors with the HIV-1 LTR promoter (Figure 1). The third domain (amino acids 38-48) is composed of LGISYG amino acids that form a hydrophobic core region. The fourth domain is a basic arginine-rich motif (49RKKRRQRRR57) [68,69], and this region plays a key role in HIV-1 Tat nuclear localization, HIV-1 Tat binding to the HIV-1 promoter region trans-activation response (TAR) $[69,70]$, and the ability of HIV-1 Tat to penetrate plasma membranes [71-73]. The arginine-rich sequence has been used to help deliver a wide variety of macromolecules into cells [74,75]. The fifth domain is a basic glutamine-rich region (residues 58-72) with highly variable genetics. Finally, the sixth domain (amino acids 73-101) is thought to be involved in the advancement of HIV-1 infectivity by supporting transcription [76,77]. 


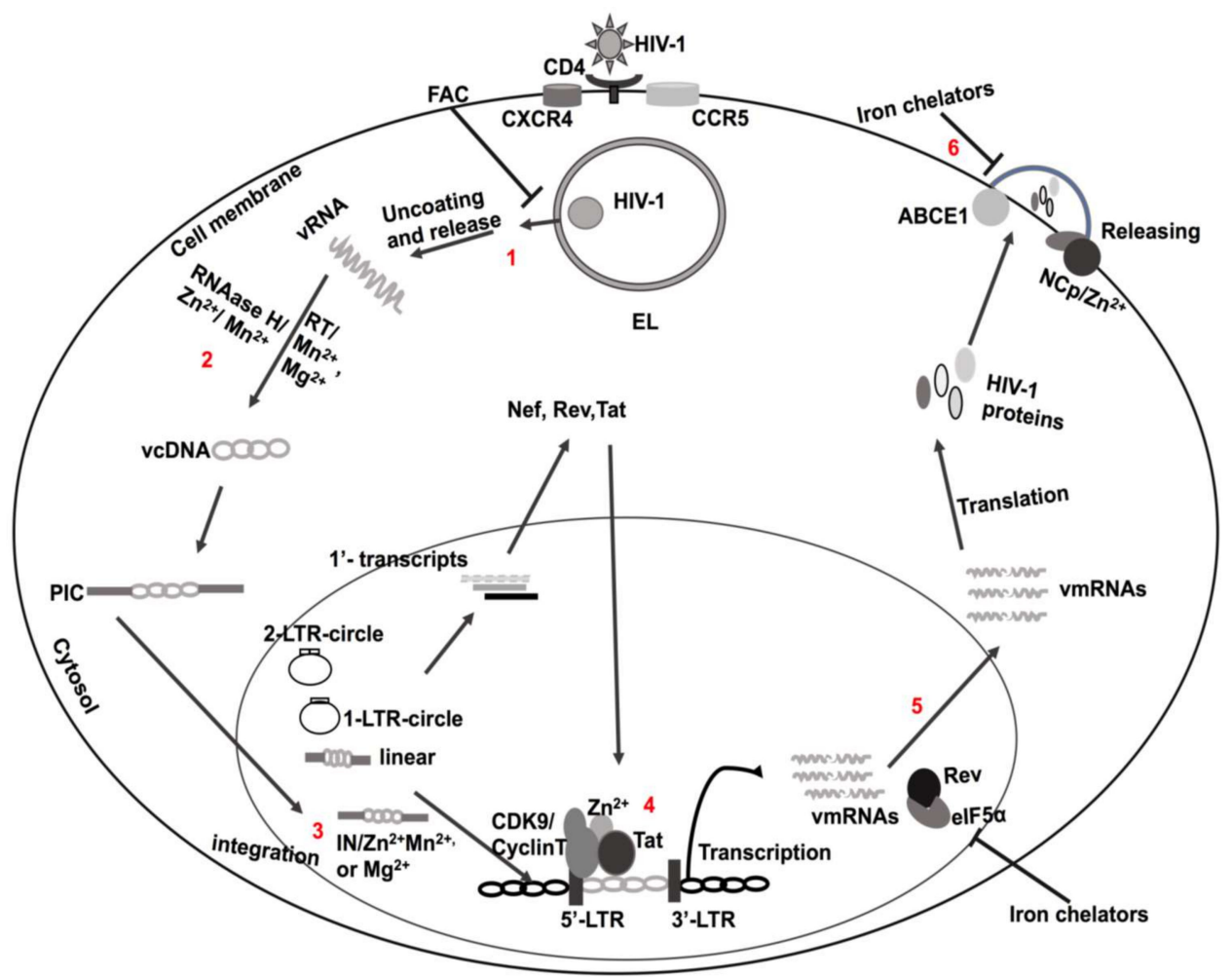

Figure 1. Roles of divalent cations in the HIV-1 life cycle and pathogenicity: 1. HIV-1 infects cells by first binding gp120 with CD4 receptors and CXCR4/CCR5 co-receptors. Post endocytosis, HIV-1 escapes from endolysosomes (EL) into the cytosol, where it is uncoated. 2. Viral RNA is reverse-transcribed into viral DNA. During reverse transcription, $\mathrm{Mn}^{2+}, \mathrm{Mg}^{2+}$, and $\mathrm{Zn}^{2+}$ control reverse transcription by regulating RNAse $\mathrm{H}$ and RT enzymes. Prior to integration, non-integrated DNA transcribes synthesis of early proteins Tat, Rev, and Nef. 3. IN requires divalent cations, including $\mathrm{Mn}^{2+} / \mathrm{Mg}^{2+}$ and $\mathrm{Zn}^{2+}$, for proper integration into the host genome. 4. Post integration, Tat elongates and terminates the transcription process of HIV-1. Zinc enhances interactions between Tat and the host factors (CycT1 and CDK9) with the HIV-1 LTR promoter for proper transcription. 5. Post transcription, HIV-1 transcripts (viral mRNAs) are transported to the cytosol by the Rev protein with the help of eIF5 $\alpha$. To be functional, eIF5 $\alpha$ needs iron. After translation, HIV-1 is transported to the cell membrane, where it assembles progeny virion particles. 6. During virus assembly, the virus needs a cellular protein, ABCE1 (ATP-binding cassette sub-family E member 1), for proper assembly by enhancing accessibility of the HIV-1 Gag protein to the virus packaging site. However, the NCp protein is also important for virus assembly to arrange the Gag protein in virion particles. Indeed, zinc is required for Gag dimerization and trafficking to the cell membrane. However, levels of divalent cations are altered in HIV-1 infection and are differentially regulated as HIV-1 disease progresses. Supplementation of divalent cations may either be beneficial or harmful to the virus, and extracellular FAC can inhibit HIV-1 escape from endolysosomes. Abbreviations: CD4: cluster differentiation 4, CXCR4: Cysteine-X-Cysteine chemokine receptor type 4, CCR5: Cysteine-Cysteine chemokine receptor type 5, Gp120: glycoprotein 120, EL: endolysosome, FAC: ferric ammonium citrate, vRNA: viral RNA, RNAse H: ribonuclease H, RT: reverse transcriptase, vcDNA: viral complementary DNA, PIC: pre-integration complex, Nef: Negative regulatory factor, IN: Integrase, CDK9: cyclin-dependent kinase 9, LTR: long terminal repeat, Tat: transactivator of transcription, vmRNAs: viral messenger RNAs, Rev: regulator of expression of virion particles, eIF5 $\alpha$ : translation initiation factor $5 \alpha$, and NCp: nucleocapsid protein.

\section{Tat-Mediated Activation of Transcription}

HIV-1 transcription starts with RNA polymerase II (RNA II) binding to the long terminal repeat (LTR) promoter along with other transcription factors [78-80]. HIV-1 Tat elongates the transcript by delivering essential transcription factors and cofactors to the TAR region of the 
LTR promoter [80-83]. Moreover, HIV-1 Tat generates a productive super elongation network by recruiting $\mathrm{p}-\mathrm{TEFb}$ (cyclin-dependent kinase CDK9 and cyclin T1 complex) and other cellular cofactors to the TAR domain [84-88] and by discharging p-TEFb from the dormant complex of 7SK small nuclear ribonucleoprotein (7SKsnRNP) and hexamethylene bis-acetamide-inducible protein 1 (HEXIM-1) [89,90]. When Tat-TAR interaction problems occur, HIV-1 transcription prematurely terminates and HIV-1 can reside inside cells in the latent phase [91,92]. However, HIV-1 can exhibit latency breakthrough resulting from modulation of Tat and TAR interactions by stimulatory factors generally $[93,94]$ and specifically by divalent cations $[95,96]$.

\section{Zinc $\left(\mathrm{Zn}^{2+}\right)$}

More than 3000 metalloenzymes and metalloproteins require $\mathrm{Zn}^{2+}$ to catalyze processes and affect cellular functions [97-99]; examples, include zinc finger proteins, metallothioneins, neuropeptides, hormone receptors, and copper-zinc superoxide dismutase (SOD) [100-103]. Additionally, $\mathrm{Zn}^{2+}$ plays an essential role in immune responses, as well as maturation and differentiation of immune cells $[103,104]$ by sequestering zinc $[105,106]$ and inducing macrophage toxicity $[106,107]$.

$\mathrm{Zn}^{2+}$ deficiency has been described for several diseases, including sickle cell anemia, malnutrition, cancer, alcoholism, uremia, and various infections. For PLWH, serum levels of $\mathrm{Zn}^{2+}$ decreased with disease progression [108-117] and clinical symptom similarities exist between HIV-1/AIDS and $\mathrm{Zn}^{2+}$ deficiency $[113,114,118]$. Further, higher mortality rates occurred in PLWH with low levels of $\mathrm{Zn}^{2+}$ [119-122], and $\mathrm{Zn}^{2+}$ deficiency and increased levels of tumor necrosis factor- $\alpha$ (TNF- $\alpha$ ) were found in people with AIDS [123-125]. $\mathrm{Zn}^{2+}$ suppresses TNF- $\alpha$ expression by maintaining higher levels of inflammatory cytokine interleukin-4 (IL-4) [126,127]. Thus, adequate levels of zinc might delay disease progression in PLWH [128].

$\mathrm{Zn}^{2+}$ is an essential cofactor of the anti-oxidative enzyme Cu-Zn SOD. Because PLWH have lower levels of $\mathrm{Zn}^{2+}$, SOD levels are reduced, and this may lead to increased lipid peroxidation, oxidative stress, and ferroptosis $[129,130]$. In contrast, HIV-1 infection was restricted when cells were supplemented with Cu-Zn SOD [131]. However, HIV-1 also uses zinc for replication and progression of infection; $\mathrm{Zn}^{2+}$ is a cofactor for integrase (IN), nucleocapsid (NCp), HIV-1 Tat, and viral infectivity factor (Vif).

Integrase is an HIV-1 encoded enzyme that catalyzes integration of the HIV-1 DNA into the host genome and $\mathrm{Zn}^{2+}$ enhances IN activity by promoting its multimerization; it does so by binding to IN cysteine domains [132-135]. The site of action of $\mathrm{Zn}^{2+}$ is likely the HIV-1 NCp protein, a nucleic acid-binding protein composed of one or two cysteine-rich domains (Cysteine $\mathrm{X}_{2}$ Cysteine $\mathrm{X}_{4}$ Histidine $\mathrm{X}_{4}$ Cysteine: $\mathrm{CCHC}$ motif) flanked by basic amino acids [136-138]. Moreover, NCp also regulates the trafficking of HIV-1 polyprotein Gag [139], HIV-1 genomic RNA (gRNA) dimerization [140,141], and generation of infectious progeny virion particles (Figure 1) [142-144].

HIV-1 Tat contains zinc-binding cysteine-rich domains, and once bound, Tat dimerizes [62,63,65,145-150]. $\mathrm{Zn}^{2+}$-mediated bridges with Cys261 domains of CycT1 facilitate Tat interactions with the HIV-1 LTR promoter region TAR [67]; these findings were confirmed using mutagenesis approaches (Figure 1) [60,67]. Following structural modification by $\mathrm{Zn}^{2+}$, Tat interacts with other cellular partners, including Cyclin T1 [67], N-methyl-d-aspartate (NMDA) receptors [151,152], and microtubules [150]. Thus, $\mathrm{Zn}^{2+}$ may affect Tat-induced HIV-1 transcription through various cellular processes [153].

Vif is an HIV-1 accessory protein that increases HIV-1 infection by inducing proteasomal degradation of anti-viral factor APOBEC3G [154]. APOBEC3G catalyzes deamination of deoxycytosine to deoxyuracil and thereby inhibits HIV-1 infectivity [155]. Vif has a cysteine repeat domain that binds $\mathrm{Zn}^{2+}$ and causes structural modification of Vif from an alpha- to a beta-sheet structure [156]. The folded beta-sheet structure of Vif promotes selective assembly of the Cullin5-E3 ligase and selects APOBEC3G 
for degradation by the proteasomal pathway [154]. The net result of increasing the degradation of anti-viral factor Vif is enhanced HIV-1 infection.

Zinc is also important for anti-viral activity of the zinc finger protein (ZAP), a host factor for multiple viruses [157]. ZAP recruits the $5^{\prime}$ - and $3^{\prime}$-mRNA degradation machinery, the net result being decreased HIV-1 mRNAs levels [158]. The tripartite motif 25 protein (TRIM25) is an essential factor for antiviral activity of the ZAP and decreases in protein expression levels of TRIM25 suppress antiviral activity of the ZAP [159].

\section{Ferrous Iron $\left(\mathrm{Fe}^{2+}\right)$}

Iron controls various cellular functions, including lysosomal activity, mitochondrial respiration, DNA synthesis, blood formation, oxygen consumption and transportation of oxygen, hormone synthesis, and cellular signaling [160]. Many metalloproteins and metalloenzymes require iron as a cofactor and are dependent on it for their actions [161]. Multiple iron-binding proteins, including lactoferrin, alpha-lipoic acid, calprotectin, transferrin, ferritin, heme oxygenase-1, ferroportin, myoglobin, mitoferrin, and hepcidin [162-165], help maintain iron homeostasis.

Homeostatic regulation of iron levels starts with the uptake of iron by intestinal enterocytes through divalent metal transporters (DMT1) [166]. Ferric iron binds with transferrin in blood [167] and iron-bound transferrin is endocytosed into acidic endolysosomes [167-170]. Once endocytosed, iron is reduced to ferrous iron, a process catalyzed by the six-transmembrane epithelial antigen of prostate 3 (STEAP3) [171]. Ferrous iron can then be transported into the cytosol through endolysosome-resident channels, including DMT1 [172] and mucolipin-1 (TRPML1) [173]. Cytosolic iron can be up-taken into other organelles through various cation channels, or it can be exported extracellularly by ferroportin.

Iron is fundamental to the production of reactive oxygen species (ROS); hydroxyl radicals are formed by the Fenton reaction [174]. When excessive, ROS causes mitochondrial dysfunction, DNA destruction [175], lipid peroxidation [175,176], and the iron-based cell death process ferroptosis [177,178]. ROS levels can be modulated by a number of factors, including SOD, catalase, glutathione peroxidase, glutathione, cysteine, ascorbic acid, and alpha-tocopherol (vitamin E) $[179,180]$.

Iron also plays essential roles in multiple stages of HIV-1 infection, including translation of viral mRNAs, virus packaging, reverse transcription, HIV-1 transcription, and nuclear factor kappa-light-chain enhancer of activated B-cells (NF-kB) activation [95,181,182]. With HIV-1 progression, iron accumulates in muscle, brain white matter, myocytes, and macrophages [183-185]; the findings were confirmed in patients with thalassemia, with haptoglobin 2-2 polymorphism, and those taking iron supplements [185]. Moreover, increased HIV-1 load correlates with increased ferritin levels in the serum of non-anemic HIV-1 infected women [186]. Additionally, higher mortality rates and increased iron levels were observed in PLWH [187].

HIV-1 proteins can disturb iron homeostasis as well as enhance HIV-1 replication and disease progression. The HIV-1 accessory protein negative regulatory factor (Nef) enhances intracellular levels of iron through the actions mediated by the human homeostatic iron regulator protein (HFE) [185]. Iron overload also occurs with HFE mutation and with hemochromatosis. Nef-induced mis-trafficking of the HFE protein to perinuclear regions near the trans-Golgi network might lead to enhanced HIV-1 infection by increasing levels of intracellular iron.

Iron regulatory host proteins are also involved in the completion of the HIV-1 life cycle. The ATP-binding cassette subfamily E member 1 (ABCE1) protein is an iron-sulfur-containing metalloprotein [188] that is involved in the assembly of newly synthesized virions at the cell membrane by direct interaction with the HIV-1 Gag protein (Figure 1.6) [189]. Furthermore, HIV-1 protein Rev requires host factor eIF5 $\alpha$ for transportation of un-spliced HIV-1 mRNAs to the cytosol from the nucleus [190,191], and iron-containing enzyme deoxyhypusine hydroxylase is required to produce hypusine, a vital part of the eIF5 $\alpha$ protein (Figure 1.5) [192]. Thus, iron chelators may restrict HIV-1 infection by decreasing the actions of the eIF5 $\alpha$ and ABCE1 proteins (Figure 1) [193]. 
Macrophages play an important role in HIV-1 infection, pathogenesis, and latency [194]. They also play important roles in regulating iron levels in red blood cells (RBCs) $[195,196]$. During hemolysis, heme stimulates iron regulatory host protein transcription of ferroportin and HO-1 [196]. The increased levels of ferroportin results in decreased levels of intracellular iron in stimulated macrophages by exporting more iron from cells $[196,197]$; mutated inactive ferroportin increases levels of intracellular iron [198]. Hepcidin is another iron regulatory host protein that enhances levels of intracellular iron, because it degrades ferroportin in endolysosomes [163]. The above findings are consistent with the findings that HIV-1 transcription is increased with high levels of intracellular iron by hepcidin-mediated decreases in ferroportin [199].

In sickle cell disease (SCD), the hepcidin protein expression levels are low [200,201] and the progression of HIV-1 infection is delayed [202,203]. SCD is a genetic disease with a single mutation in the beta-globin gene that is characterized by chronic hemolytic anemia (hemolysis) [204]. With hemolysis, there is an increased release of heme from hemoglobin and increased expression levels of multiple iron regulatory factors, including ferroportin, $\mathrm{HO}-1$, p21, and biliverdin reductase. However, somewhat paradoxically, intracellular iron levels are decreased [205] and, because of this, activity levels of CDK2 are decreased [206,207]. Decreased CDK2 activates SAMHD1 (sterile alpha motif and histidine/aspartic acid (HD) domain-containing protein 1) by enhancing its dephosphorylation [208]. HIV-1 reverse transcription is restricted by dephosphorylated SAMHD1 (active). However, at adequate levels of iron, active CDK2 increased inactive levels of SAMHD1 and increased HIV-1 replication [209,210]. Elevated levels of the p21 protein are linked to increased activation of SAMHD1 in HIV-1 elite controllers [211], increased Egr-1 (early growth response) [212], which is regulated by the hypoxia-inducible factor (HIF-1a) [212,213], and SCD when iron levels are low [214]. Furthermore, various studies have shown that hemin-produced HO-1 efficiently restricts HIV-1 infection by reducing intracellular iron levels [214,215]. HIV-1 infection was restricted by hemin treatment; the findings were similar to those showing inhibition of HIV-1 in individuals with SCD [216,217].

Protein phosphatase-1 (PP1) activity increases HIV-1 transcription, likely because of its effects on iron and HIF- $1 \alpha$. A low level of iron decreases PP1 catalytic activity and increases HIF-1 $\alpha[218,219]$. PP1 also increases HIV-1 transcription by releasing CDK9 from the inactive complex of 7SKRNP and HEXIM1 [220,221]. PP1 expression can be negatively regulated by hypoxia either by limiting levels of mRNA [222] or mRNA transports to the nucleus [223,224]. Hypoxia suppressed HIV-1 replication by decreasing CDK9 activity and/or inactivating PP1 [224,225]. Nonetheless, HIV-1 can overcome the effects of the PP1 protein on HIV-1 replication by enhancing PP1 transport to the nucleus by Tat and increasing the actions of CDK9.

Because iron is important for HIV-1 replication, intracellular iron chelators have been investigated for their ability to control HIV-1 (Figure 1) [226,227]. Deferiprone, fungicide, and ciclopirox all reduced levels of HIV-1 gene expression at the transcription level by targeting cellular factor eIF5 $\alpha$ [193,206,207]. Additionally, deferasirox, Bp4aT, Bp4eT, and iron chelator 311 suppressed HIV-1 replication by targeting CDK2 and CDK9 [228-230]. Moreover, CDK2 inactivation by iron chelators was associated with cyclin-dependent kinase inhibitors p27 (Kip1) and p21 (CIP1/WAF1) [229,230]. Higher levels of p21 have been reported in PLWH [231]. However, HIV-1 production was increased when p21 expression levels were decreased [211]. Thus, p21 may restrict HIV-1 infection through anti-CDK2/9 properties [231-233] and CDK2 phosphorylation effects of HIV-1 Tat may enhance HIV-1 infection [234-236]. In addition, cyclin A (S phase transition) and cyclin E (G1/S phase transition) can regulate CDK2 at different cell cycle stages [236].

Extracellular iron can also restrict HIV-1 replication and infection. Extracellular ferric ammonium citrate (FAC) restricted HIV-1 infection by inhibiting the release of HIV-1 from endolysosomes; it increased the fusion of vesicles in host cells (Figure 1) [237]. Iron may also decrease HIV-1 by restricting the ability of HIV-1 Tat to bind to the TAR region of the HIV-1 LTR promoter [238]. Iron overload also suppressed HIV-1 replication by decreasing Rev cofactor eIF5 $\alpha$ [239]. 
Iron can also play an important role in HIV-1 latency [240]. Iron can reactivate HIV-1 replication by inducing oxidative stress [241]. On the other hand, iron chelators may restrict HIV-1 reactivation by decreasing oxidative stress, reducing expression of anti-HIV-1 factor beta-catenin, and blocking cell proliferation $[242,243]$. However, much more work is needed to understand better the possible therapeutic use of iron chelators in HIV-1 latency, including reservoirs in the CNS [58].

\section{Manganese $\left(\mathrm{Mn}^{2+}\right)$ and Magnesium $\left(\mathrm{Mg}^{2+}\right)$}

Manganese is a cofactor of numerous metalloenzymes, including manganese superoxide dismutase (Mn-SOD) [244,245], pyruvate carboxylase [246], and glutamate synthetase [247,248]. Manganese is also required for mucopolysaccharide metabolism, oxidative phosphorylation, and oxidative stress [249]. Increased oxidative stress can result in higher levels of HIV-1 and increases in Mn-SOD have been observed in HIV-1 infection; increased Mn-SOD may help protect HIV-1-infected cells from cell death $[250,251]$.

The ability of manganese to control HIV-1 replication appears to be mediated through its actions on reverse transcriptase (RT) and integrase (IN) enzyme activity. RT is essential for reverse transcription of viral DNA from viral RNA. RT is composed of the p66 and p51 subunits driven by viral proteases from the Gag-Pol polyprotein and RT activity requires divalent cations, including $\mathrm{Mn}^{2+}$ and $\mathrm{Mg}^{2+}$ [252]. The two subunits are necessary for DNA polymerase and RNAase $\mathrm{H}$ activity and produce double-stranded DNA (ds-DNA) [253,254]. RNAase H (p51) has binding sites for divalent cations [255-257]; $\mathrm{Mn}^{2+}$ and $\mathrm{Mg}^{2+}$ binding at D442, E478, D498, and D549 results in stimulation of enzymatic activity (Figure 1) $[258,259]$. Moreover, $\mathrm{Mn}^{2+}$ can modify $\mathrm{RT}$ substrate specificity and increase RT mutations $[260,261]$.

IN is essential for the integration of HIV-1 DNA into the host genome [262-264] and $\mathrm{Mn}^{2+}$ and $\mathrm{Mg}^{2+}$ are known cofactors for integrase activity [265]. IN contains three domains; $\mathrm{N}$-terminal, C-terminal, and catalytic domains [265]. The N-terminal domain contains a highly conserved cysteine repeat domain (the CCHC domain), which is a binding site of $\mathrm{Zn}^{2+}$ ions; the binding of $\mathrm{Zn}^{2+}$ stabilizes IN and induces IN multimerization [132]. The active site contains an extremely conserved region that is required for $\mathrm{Mn}^{2+}$ and $\mathrm{Mg}^{2+}$ binding as well as viral integration (Figure 1.3) $[135,266]$ into the viral but not the host DNA [264]. Some IN inhibitors restrict the integration process by chelating $\mathrm{Mn}^{2+}$ or $\mathrm{Mg}^{2+}$ cations, for example, catechols and beta-ketoenols [267]. Therefore, the IN enzyme is a unique and favorable therapeutic target to inhibit HIV-1 infection.

\section{Selenium $\left(\mathrm{Se}^{2+}\right)$}

Selenium is essential for cellular antioxidant defense mechanisms, including glutathione peroxidase, SOD, and other selenoproteins [268,269]. Inadequate levels of selenium are associated with gastroenteritis and dermatitis, impaired thyroid hormone metabolism [270], cancers [271], male subfertility, liver dysfunctions [272], weakened immune functions [273], liver dysfunctions, mood disorders, and progression of HIV-1 infection and mortality [38,121,122,274]. With lower levels of selenium, PLWH have higher levels of oxidative stress, increased opportunistic infections, increased viral load, and higher mortality rates [122,274-276].

Therapeutically, it is recommended that people ingest selenium (200 $\mu \mathrm{g} / \mathrm{day})$ and studies have shown that this reduces viral load, diminishes HIV-1 infection of monocytes, and reduces the number of CD4+ T-cells [277-282]. However, not all studies found protective effects of selenium against the HIV-1 viral load and CD4+ cells in PLWH $[283,284]$. Selenium supplementation has also been shown to be protective against strokes, possibly by suppressing oxidative stress and blocking ferroptosis [285].

\section{Copper $\left(\mathrm{Cu}^{2+}\right)$}

Copper, too, is an essential cofactor of multiple metalloenzymes and metalloproteins as well as an important part of the cellular anti-oxidative system [286]. Copper has anti-microbial 
properties by radical and non-radical mechanisms [287] and by phagosome-burst and -maturation mechanisms $[107,288]$. However, pathogens can resist the actions of copper by sorting it into siderophore structures [289].

Copper, zinc, cysteine, and glutathione all effectively inhibit HIV-1 [119,120,290,291]. Cysteine and glutathione are essential parts of SOD and catalase, which block HIV-1-mediated oxidative stress and its consequences [292-295]. Copper and zinc are released from metallothionine by glutathione and thereby become biologically active. $\mathrm{Zn}^{2+}$ can either facilitate HIV-1 infection or it can inhibit the production of mature and infectious virus particles by inhibiting HIV-1 protease activity [296]. Similar to zinc, copper can inhibit HIV-1 protease activity by binding directly to cysteine amino acids [297]. Therefore, sufficient $\mathrm{Cu}^{2+}, \mathrm{Zn}^{2+}$, glutathione, and cysteine can control HIV-1 infection [290]. Moreover, extracellular copper/zinc SOD has anti-HIV-1 effects [298] and reduces neurotoxic effects of HIV-1 proteins [299,300] by controlling oxidative stress. Additionally, copper oxide contained in latex, polymeric materials, filter matrices and fibers has virucidal activity [301]; copper-coated filters neutralized HIV-1 virus particles [302,303] and copper oxide restricted HIV-1 transmission from breast milk [304].

\section{Roles of Divalent Cations in HIV-1 Tat-Mediated Pathogenicity}

HIV-1 Tat continues to be implicated in the pathogenesis of HAND [305-307]. As such, it is known as a virotoxin [306,307]. In PLWH, HIV-1 Tat is present in plasma and cerebrospinal fluid (CSF), and its levels can stay elevated even when virus levels were effectively controlled by ART [308]. HIV-1 negatively affects neurons by increasing levels of intracellular calcium [309,310], increasing ROS [130], and causing bioenergetic failure [311]. HIV-1 Tat contains an arginine-rich domain (Tat 48-60) that causes it to be up-taken into cells by receptor-mediated endocytosis [71,73]; this same feature is used experimentally to enhance the uptake into cells of a wide variety of macromolecules [75]. The receptors to which HIV-1 Tat binds include low-density lipoprotein receptor 1 [55], CXCR4, heparin sulfate proteoglycan [312], and CD26 [56,313,314]. Following its endocytosis, HIV-1 Tat associates with endolysosomes $[53,55,315]$. However, HIV-1 Tat must escape from endolysosomes to activate the HIV-1 LTR in the nucleus [56,316,317], a process known to be mediated by endolysosome de-acidification and calcium [315-317]. However, the underlying mechanisms responsible for Tat escape from endolysosomes remain poorly defined (Figure 2).

In addition to its active secretion from infected cells, HIV-1 Tat and Tat mRNAs can also exit cells via released extracellular vesicles (exosomes) and this released material might then be taken up by an uninfected bystander cell to enhance HIV-1 pathogenicity [318,319]. Secreted Tat has been shown to modify activator protein-1 (AP-1), nuclear factor kappa-light-chain enhancer of activated B-cells $(\mathrm{NF}-\mathrm{kB})$, and cAMP responsive element-binding protein (CREB) transcription factors and affect diverse cellular signaling pathways [320-325]. Secreted Tat impairs endolysosome membrane integrity and degradation pathways [326]; the changes noted include changes in their $\mathrm{pH}$, distribution patterns, sizes, and membrane integrity [326,327]. Endolysosome de-acidification may also affect the cation contents of endolysosomes, including the cations discussed above: $\mathrm{Fe}^{2+}, \mathrm{Cu}^{2+}, \mathrm{Mn}^{2+}, \mathrm{Mg}^{2+}, \mathrm{Zn}^{2+}$, and $\mathrm{Cd}^{2+}$. To varying extents, divalent cations can promote the oligomerization of Tat by binding to its cysteine-rich domain $[65,66,328]$. As discussed above, $\mathrm{Zn}^{2+}$ plays a role in inducing conformational changes to and physiological actions of Tat [149-152]. In addition to $\mathrm{Zn}^{2+}$, iron also induces HIV-1 Tat oligomerization (unpublished) (Figure 2), an action possibly mediated by iron-induced ROS production and iron-induced oxidation and oligomerization of HIV-1 Tat (Figure 2) [329]. These effects of iron may be especially relevant in older PLWH, because iron is aggregated in aged brains, and it is known to induce accumulation of the $\beta$-amyloid, $p$-Tau and $\alpha$-synuclein proteins [330-332]. 


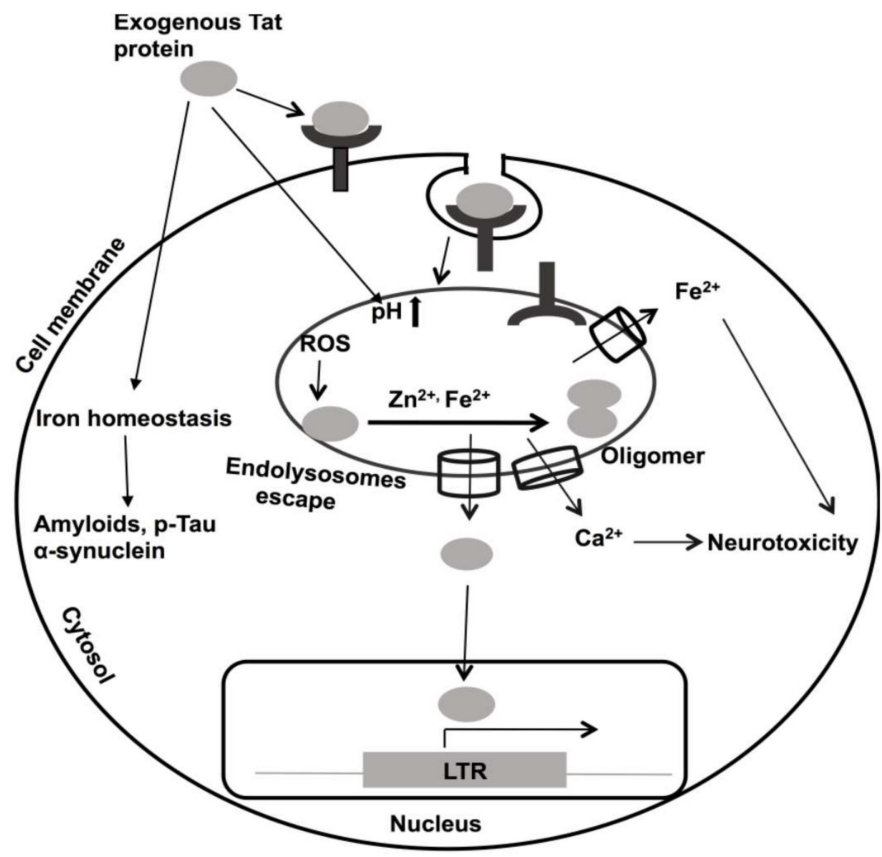

Figure 2. Roles of divalent cations in HIV-1 Tat-mediated pathogenicity. Extracellular Tat is a neurotoxin implicated in the pathogenesis of HIV-1-associated neurocognitive disorders (HAND). Tat enters bystander cells by receptor-mediated endocytosis. Internalized Tat disturbs endolysosome functions, including de-acidification. When de-acidified, Tat is released from endolysosomes and enters the nucleus where it activates HIV-1 LTR transactivation. Endolysosomes contain divalent cations and these can induce Tat oligomerization. Because Tat oxidizes rapidly, Tat can be oxidized by iron-induced reactive oxygen species (ROS). Disturbed iron homeostasis may be involved in increasing levels of various neurotoxic substances, including $\beta$-amyloid, p-Tau, and $\alpha$-synuclein.

\section{Summary}

Divalent cations are involved in the pathogenesis of HIV-1 as well as the ability of the host to control HIV-1 replication. However, the extent to which divalent cations are beneficial or harmful to PLWH is not clear. Thus, caution might be advised about divalent cation supplementation to PLWH. This might be especially true for iron; because it is highly abundant, it plays important roles in regulating HIV-1 infection, and iron level are elevated as HIV-1 infection progresses. Further, the use of iron chelators might inhibit HIV-1 replication and progression. Moreover, the iron homeostasis disturbed by HIV-1 and HIV-1 Tat may regulate expression of anti-HIV-1 cellular factors and immune responses by iron regulatory proteins hepcidin and ferroportin [333]. More comprehensive examinations are required to determine biological effects of divalent cations in HIV-1 infection and this information might inform the development of novel therapeutic strategies.

Author Contributions: All authors performed a major role in conceptualizing, writing, and proofreading this manuscript. All authors have read and agreed to the published version of the manuscript.

Funding: We gratefully acknowledge research funding support provided by the National Institute of Health (NIH), USA; P30GM100329, U54GM115458, R01MH100972, R01MH105329, R01MH119000, 2R01NS065957, and 2R01DA032444.

Conflicts of Interest: The authors disclose that this manuscript was written without any commercial or financial associations that could be construed as a conflict of interest.

\section{References}

1. Anastassopoulou, J.; Theophanides, T. The Role of Metal Ions in Biological Systems and Medicine. In Bioinorganic Chemistry: An Inorganic Perspective of Life; Kessissoglou, D.P., Ed.; Springer: Dordrecht, The Netherlands, 1995; pp. 209-2018. 
2. Sigel, A.; Sigel, H.; Sigel, R.K.O. Interactions Between Essential Metal Ions and Human Diseases; Springer: Dordrecht, The Netherlands, 2013.

3. Delgado, R.; Vergara, C.; Wolff, D. Divalent Cations as Modulators of Neuronal Excitability: Emphasis on Copper and Zinc. Biol. Res. 2006, 39, 173-182. [CrossRef]

4. Bloom, A.J. Metal Regulation of Metabolism. Curr. Opin. Chem. Biol. 2019, 49, 33-38. [CrossRef]

5. Tan, X. Metalloproteins and Metalloenzymes: Roles and Mechanisms of Metals in Functional Proteins; World Scientific Publishing Company Pte Limited: Singapore, 2018.

6. Baier, F.; Chen, J.; Solomonson, M.; Strynadka, N.C.J.; Tokuriki, N. Distinct Metal Isoforms Underlie Promiscuous Activity Profiles of Metalloenzymes. ACS Chem. Biol. 2015, 10, 1684-1693. [CrossRef] [PubMed]

7. Hausinger, R.P. New Metal Cofactors and recent Metallocofactor insights. Curr. Opin. Struct. Biol. 2019, 59, 1-8. [CrossRef] [PubMed]

8. Pernil, R.; Schleiff, E. Metalloproteins in the Biology of Heterocysts. Life 2019, 9, 32. [CrossRef] [PubMed]

9. Hoppert, M. Metalloenzymes. In Encyclopedia of Geobiology; Reitner, J., Thiel, V., Eds.; Springer: Dordrecht, The Netherlands, 2011; pp. 558-563.

10. Knape, M.J.; Herberg, F.W. Metal Coordination in Kinases and Pseudokinases. Biochem. Soc. Trans. 2017, 45, 653-663. [CrossRef]

11. Walker, G.M.; Duffus, J.H. Magnesium Ions and the Control of the Cell Cycle in Yeast. J. Cell. Sci. 1980, 42, 329-356.

12. Mackenzie, K.; Foot, N.J.; Anand, S.; Dalton, H.E.; Chaudhary, N.; Collins, B.M.; Mathivanan, S.; Kumar, S. Regulation of the Divalent Metal Ion Transporter via Membrane Budding. Cell. Discov. 2016, 2, 16011. [CrossRef]

13. Zhang-Keck, Z.Y.; Eckstein, F.; Washington, L.D.; Stallcup, M.R. A Role for Divalent Cations in Specifying the start site for transcription from chromatin templates in vitro. J. Biol. Chem. 1988, 263, 9550-9556.

14. Chaigne-Delalande, B.; Lenardo, M.J. Divalent cation signaling in immune cells. Trends Immunol. 2014, 35 , 332-344. [CrossRef]

15. Diaz-Ochoa, V.E.; Jellbauer, S.; Klaus, S.; Raffatellu, M. Transition metal ions at the crossroads of mucosal immunity and microbial pathogenesis. Front. Cell Infect. Microbiol. 2014, 4, 2. [CrossRef] [PubMed]

16. Zhang, K.; Chen, J. The regulation of integrin function by divalent cations. Cell Adh. Migr. 2012, 6, $20-29$. [CrossRef] [PubMed]

17. Stelling, M.P.; Motta, J.M.; Mashid, M.; Johnson, W.E.; Pavão, M.S.; Farrell, N.P. Metal ions and the extracellular matrix in tumor migration. FEBS J. 2019, 286, 2950-2964. [CrossRef] [PubMed]

18. Hamatake, M.; Iguchi, K.; Hirano, K.; Ishida, R. Zinc Induces Mixed Types of Cell Death, Necrosis, and Apoptosis, in Molt-4 Cells. J. Biochem. 2000, 128, 933-939. [CrossRef]

19. Liang, Q.; Zhou, B. Copper and Manganese Induce Yeast Apoptosis via Different Pathways. Mol. Biol. Cell. 2007, 18, 4741-4749. [CrossRef]

20. Yeo, J.E.; Kang, S.K. Selenium effectively inhibits ROS-mediated apoptotic neural precursor cell death in vitro and in vivo in traumatic brain injury. Biochim. Biophys. Acta 2007, 1772, 1199-1210. [CrossRef]

21. Coffin, A.B.; Reinhart, K.E.; Owens, K.N.; Raible, D.W.; Rubel, E.W. Extracellular divalent cations modulate aminoglycoside-induced hair cell death in the zebrafish lateral line. Hear Res. 2009, 253, 42-51. [CrossRef]

22. Dribben, W.H.; Eisenman, L.N.; Mennerick, S. Magnesium induces neuronal apoptosis by suppressing excitability. Cell Death Dis. 2010, 1, e63. [CrossRef]

23. Mou, Y.; Wang, J.; Wu, J.; He, D.; Zhang, C.; Duan, C.; Li, B. Ferroptosis, a new form of cell death: Opportunities and challenges in cancer. J. Hematol. Oncol. 2019, 12, 34. [CrossRef]

24. P. Aisen, A.; Listowsky, I. Iron Transport and Storage Proteins. Annu. Rev. Biochem. 1980, 49, $357-393$. [CrossRef]

25. Coleman, J.E. ZINC PROTEINS: Enzymes, Storage Proteins, Transcription Factors, and Replication Proteins. Annu. Rev. Biochem. 1992, 61, 897-946. [CrossRef] [PubMed]

26. Sigel, A.; Sigel, H. Metal ions in biological systems, volume 35: Iron transport and storage microorganisms, plants, and animals. Met. Based Drugs 1998, 5, 262. [CrossRef] [PubMed]

27. Rolfs, A.; Hediger, M.A. Metal ion transporters in mammals: Structure, function and pathological implications. J. Physiol. 1999, 518, 1-12. [CrossRef] [PubMed]

28. Eide, D.J. Zinc transporters and the cellular trafficking of zinc. Biochim. Biophys. Acta 2006, 1763, 711-722. [CrossRef] [PubMed] 
29. Prohaska, J.R. Role of copper transporters in copper homeostasis. Am. J. Clin. Nutr. 2008, 88, 826S-829S. [CrossRef] [PubMed]

30. Zhao, N.; Enns, C.A. Iron transport machinery of human cells: Players and their interactions. Curr. Top. Membr. 2012, 69, 67-93.

31. Botella, H.; Stadthagen, G.; Lugo-Villarino, G.; de Chastellier, C.; Neyrolles, O. Metallobiology of host-pathogen interactions: An intoxicating new insight. Trends Microbiol. 2012, 20, 106-112. [CrossRef]

32. Hood, M.I.; Skaar, E.P. Nutritional immunity: Transition metals at the pathogen-host interface. Nat. Rev. Microbiol. 2012, 10, 525-537. [CrossRef]

33. Veyrier, F.J.; Cellier, M.F. Metal economy in host-microbe interactions. Front. Cell Infect. Microbiol. $2015,4$. [CrossRef]

34. Skaar, E.P.; Raffatellu, M. Metals in infectious diseases and nutritional immunity. Metallomics 2015, 7, 926-928. [CrossRef]

35. Weiss, G.; Carver, P.L. Role of divalent metals in infectious disease susceptibility and outcome. Clin. Microbiol. Infect. 2018, 24, 16-23. [CrossRef] [PubMed]

36. Baum, M.K.; Campa, A.; Lai, S.; Lai, H.; Page, J.B. Zinc Status in Human Immunodeficiency Virus Type 1 Infection and Illicit Drug Use. Clin. Infect. Dis. 2003, 37 (Suppl. 2), S117-S123. [CrossRef] [PubMed]

37. Irlam, J.J.H.; Visser, M.M.E.; Rollins, N.N.; Siegfried, N. Micronutrient supplementation in children and adults with HIV infection. Cochrane Database Syst. Rev. 2005, 19, CD003650.

38. Kassu, A.; Yabutani, T.; Mahmud, Z.H.; Mohammad, A.; Nguyen, N.; Huong, B.T.M.; Hailemariam, G.; Diro, E.; Ayele, B.; Wondmikun, Y.; et al. Alterations in serum levels of trace elements in tuberculosis and HIV infections. Eur. J. Clin. Nutr. 2006, 60, 580-586. [CrossRef]

39. Friis, H. Micronutrient interventions and HIV infection: A review of current evidence. Trop. Med. Int. Health 2007, 11, 1849-1857. [CrossRef]

40. Banjoko, S.; Oseni, F.; Togun, R.; Onayemi, O.; Emma-Okon, B.; Fakunle, J. Iron status in HIV-1 infection: Implications in disease pathology. BMC Clin. Pathol. 2012, 12, 26. [CrossRef]

41. Chang, H.-C.; Bayeva, M.; Taiwo, B.; Palella, F.J., Jr.; Hope, T.J.; Ardehali, H. Short communication: High cellular iron levels are associated with increased HIV infection and replication. AIDS Res. Hum. Retroviruses 2015, 31, 305-312. [CrossRef]

42. Cooper, D.A. Life and death in the cART era. Lancet 2008, 372, 266-267. [CrossRef]

43. Kwong, P.D.; Wyatt, R.; Robinson, J.; Sweet, R.W.; Sodroski, J.; Hendrickson, W.A. Structure of an HIV gp120 envelope glycoprotein in complex with the CD4 receptor and a neutralizing human antibody. Nature 1998, 393, 648-659. [CrossRef]

44. Frankel, A.D.; Young, J.A.T. HIV-1: Fifteen Proteins and an RNA. Annu. Rev. Biochem. 1998, 67, 1-25. [CrossRef]

45. Zeichner, S.L. The Molecular Biology of HIV: Insights Into Pathogenesis and Targets for Therapy. Clin. Perinatol. 1994, 21, 39-73. [CrossRef]

46. Freed, E.O. HIV-1 Replication. Somat. Cell Mol. Genet. 2001, 26, 13-33. [CrossRef] [PubMed]

47. Campbell, S.M.; Crowe, S.M.; Mak, J. Lipid rafts and HIV-1: From viral entry to assembly of progeny virions. J. Clin. Virol. 2001, 22, 217-227. [CrossRef]

48. Das, A.T.; Harwig, A.; Berkhout, B. The HIV-1 Tat protein has a versatile role in activating viral transcription. J. Virol. 2011, 85, 9506-9516. [CrossRef]

49. Liang, C.; Wainberg, M. The role of Tat in HIV-1 replication: An activator and/or a suppressor? AIDS Rev. 2002, 4, 41-49.

50. Romani, B.; Engelbrecht, S.; Glashoff, R.H. Functions of Tat: The versatile protein of human immunodeficiency virus type 1. J. Gen. Virol. 2010, 91, 1-12. [CrossRef]

51. Li, L.; Dahiya, S.; Kortagere, S.; Aiamkitsumrit, B.; Cunningham, D.; Pirrone, V.; Nonnemacher, M.R.; Wigdahl, B. Impact of Tat Genetic Variation on HIV-1 Disease. Adv. Virol. 2012, 2012, 123605. [CrossRef]

52. Rice, A.P. The HIV-1 Tat Protein: Mechanism of Action and Target for HIV-1 Cure Strategies. Curr. Pharm. Des. 2017, 23, 4098-4102. [CrossRef]

53. Frankel, A.D.; Pabo, C.O. Cellular uptake of the tat protein from human immunodeficiency virus. Cell 1988, 55, 1189-1193. [CrossRef]

54. Mann, D.A.; Frankel, A.D. Endocytosis and targeting of exogenous HIV-1 Tat protein. EMBO J. 1991, 10, 1733-1739. [CrossRef] 
55. Liu, Y.; Jones, M.; Hingtgen, C.M.; Bu, G.; Laribee, N.; Tanzi, R.E.; Moir, R.D.; Nath, A.; He, J.J. Uptake of HIV-1 tat protein mediated by low-density lipoprotein receptor-related protein disrupts the neuronal metabolic balance of the receptor ligands. Nat. Med. 2000, 6, 1380-1387. [CrossRef] [PubMed]

56. Kolson, D.L.; Collman, R.; Hrin, R.; Balliet, J.W.; Laughlin, M.; McGann, K.A.; Debouck, C.; Gonzalez-Scarano, F. Human immunodeficiency virus type 1 Tat activity in human neuronal cells: Uptake and trans-activation. J. Gen. Virol 1994, 75, 1927-1934. [CrossRef] [PubMed]

57. Heaton, R.K.; Clifford, D.B.; Franklin, D.R., Jr.; Woods, S.P.; Ake, C.; Vaida, F.; Ellis, R.J.; Letendre, S.L.; Marcotte, T.D.; Atkinson, J.H.; et al. HIV-associated neurocognitive disorders persist in the era of potent antiretroviral therapy: CHARTER Study. Neurology 2010, 75, 2087-2096. [CrossRef] [PubMed]

58. Spudich, S.; Gonzalez-Scarano, F. HIV-1-related central nervous system disease: Current issues in pathogenesis, diagnosis, and treatment. Cold Spring Harb. Perspect. Med. 2012, 2, a007120. [CrossRef]

59. Bagashev, A.; Sawaya, B.E. Roles and functions of HIV-1 Tat protein in the CNS: An overview. Virol. J. 2013, 10, 358. [CrossRef]

60. Garcia, J.A.; Harrich, D.; Soultanakis, E.; Wu, F.; Mitsuyasu, R.; Gaynor, R.B. Human immunodeficiency virus type 1 LTR TATA and TAR region sequences required for transcriptional regulation. EMBO J. 1989, 8 , 765-778. [CrossRef]

61. Rana, T.M.; Jeang, K.-T. Biochemical and Functional Interactions between HIV-1 Tat Protein and TAR RNA. Arch. Biochem. Biophys 1999, 365, 175-185. [CrossRef]

62. Kuppuswamy, M.; Subramanian, T.; Srinivasan, A.; Chinnadurai, G. Multiple functional domains of Tat, the trans-activator of HIV-1, defined by mutational analysis. Nucleic Acids Res. 1989, 17, 3551-3561. [CrossRef]

63. Jeang, K.T.; Xiao, H.; Rich, E.A. Multifaceted activities of the HIV-1 transactivator of transcription. Tat. J. Biol. Chem. 1999, 274, 28837-28840. [CrossRef]

64. López-Huertas, M.R.; Callejas, S.; Abia, D.; Mateos, E.; Dopazo, A.; Alcamí, J.; Coiras, M. Modifications in host cell cytoskeleton structure and function mediated by intracellular HIV-1 Tat protein are greatly dependent on the second coding exon. Nucleic Acids Res. 2010, 38, 3287-3307. [CrossRef]

65. Frankel, A.; Bredt, D.; Pabo, C. Tat protein from human immunodeficiency virus forms a metal-linked dimer. Science 1988, 240, 70-73. [CrossRef] [PubMed]

66. Kalantari, P.; Ayan, V.; Natarajan, S.K.; Muralidhar, K.; Gandhi, U.H.; Vunta, H.; Henderson, A.J.; Prabhu, K.S. Thioredoxin reductase-1 negatively regulates HIV-1 transactivating protein Tat-dependent transcription in human macrophages. J. Biol. Chem. 2008, 283, 33183-33190. [CrossRef] [PubMed]

67. Garber, M.E.; Wei, P.; KewalRamani, V.N.; Mayall, T.P.; Herrmann, C.H.; Rice, A.P.; Littman, D.R.; Jones, K.A. The interaction between HIV-1 Tat and human cyclin T1 requires zinc and a critical cysteine residue that is not conserved in the murine CycT1 protein. Genes Dev. 1998, 12, 3512-3527. [CrossRef] [PubMed]

68. Dingwall, C.; Ernberg, I.; Gait, M.J.; Green, S.M.; Heaphy, S.; Karn, J.; Lowe, A.D.; Singh, M.; Skinner, M.A.; Valerio, R. Human immunodeficiency virus 1 tat protein binds trans-activation-responsive region (TAR) RNA in vitro. Proc. Natl. Acad. Sci. USA 1989, 86, 6925-6929. [CrossRef]

69. Roy, S.; Delling, U.; Chen, C.H.; Rosen, C.A.; Sonenberg, N. A bulge structure in HIV-1 TAR RNA is required for Tat binding and Tat-mediated trans-activation. Genes Dev. 1990, 4, 1365-1373. [CrossRef]

70. Weeks, K.M.; Crothers, D.M. RNA recognition by Tat-derived peptides: Interaction in the major groove? Cell 1991, 66, 577-588. [CrossRef]

71. Hauber, J.; Malim, M.H.; Cullen, B.R. Mutational analysis of the conserved basic domain of human immunodeficiency virus tat protein. J. Virol. 1989, 63, 1181-1187. [CrossRef]

72. Ruben, S.; Perkins, A.; Purcell, R.; Joung, K.; Sia, R.; Burghoff, R.; Haseltine, W.A.; Rosen, C.A. Structural and functional characterization of human immunodeficiency virus tat protein. J. Virol. 1989, 63, 1-8. [CrossRef]

73. Schwarze, S.R.; Hruska, K.A.; Dowdy, S.F. Protein transduction: Unrestricted delivery into all cells? Trends Cell Biol. 2000, 10, 290-295. [CrossRef]

74. Fuchs, S.M.; Raines, R.T. Internalization of cationic peptides: The road less (or more?) traveled. Cell. Mol. Life Sci. 2006, 63, 1819-1822. [CrossRef]

75. El-Sayed, A.; Futaki, S.; Harashima, H. Delivery of macromolecules using arginine-rich cell-penetrating peptides: Ways to overcome endosomal entrapment. AAPS J. 2009, 11, 13-22. [CrossRef] [PubMed]

76. Neuveut, C.; Scoggins, R.M.; Camerini, D.; Markham, R.B.; Jeang, K.-T. Requirement for the second coding exon of Tat in the optimal replication of macrophage-tropic HIV-1. J. Biomed. Sci. 2003, 10, 651-660. [CrossRef] [PubMed] 
77. Mahlknecht, U.; Dichamp, I.; Varin, A.; Van Lint, C.; Herbein, G. NF-kB-dependent control of HIV-1 transcription by the second coding exon of Tat in T cells. J. Leukoc. Biol. 2008, 83, 718-727. [CrossRef] [PubMed]

78. Huh, J.R.; Park, J.M.; Kim, M.; Carlson, B.A.; Hatfield, D.L.; Lee, B.J. Recruitment of TBP or TFIIB to a Promoter Proximal Position Leads to Stimulation of RNA Polymerase II Transcription without Activator Proteins bothin Vivoandin Vitro. Biochem. Biophys. Res. Commun. 1999, 256, 45-51. [CrossRef]

79. Zhou, M.; Halanski, M.A.; Radonovich, M.F.; Kashanchi, F.; Peng, J.; Price, D.H.; Brady, J.N. Tat Modifies the Activity of CDK9 To Phosphorylate Serine 5 of the RNA Polymerase II Carboxyl-Terminal Domain during Human Immunodeficiency Virus Type 1 Transcription. Mol. Cell Biol. 2000, 20, 5077-5086. [CrossRef]

80. Ping, Y.H.; Rana, T.M. DSIF and NELF interact with RNA polymerase II elongation complex and HIV-1 Tat stimulates P-TEFb-mediated phosphorylation of RNA polymerase II and DSIF during transcription elongation. J. Biol. Chem. 2001, 276, 12951-12958. [CrossRef]

81. Parada, C.A.; Roeder, R.G. Enhanced processivity of RNA polymerase II triggered by Tat-induced phosphorylation of its carboxy-terminal domain. Nature 1996, 384, 375-378. [CrossRef]

82. Cujec, T.P.; Okamoto, H.; Fujinaga, K.; Meyer, J.; Chamberlin, H.; Morgan, D.O.; Peterlin, B.M. The HIV transactivator TAT binds to the CDK-activating kinase and activates the phosphorylation of the carboxy-terminal domain of RNA polymerase II. Genes Dev. 1997, 11, 2645-2657. [CrossRef]

83. Anne, P.; Longwen, D.; Anil, M.; Cynthia de la, F.; Hong, L.; John, D.W.; Paul, L.; Ajit, K.; Fatah, K. Chromatin Remodeling and Modification during HIV-1 Tat-activated Transcription. Curr. HIV Res. 2003, 1, 343-362.

84. Price, D.H. P-TEFb, a cyclin-dependent kinase controlling elongation by RNA polymerase II. Mol. Cell Biol. 2000, 20, 2629-2634. [CrossRef]

85. Romano, G.; Kasten, M.; Falco, G.; Micheli, P.; Khalili, K.; Giordano, A. Regulatory functions of Cdk9 and of cyclin T1 in HIV tat transactivation pathway gene expression. J. Cell Biochem. 2000, 75, 357-368. [CrossRef]

86. Zhu, Y.; Pe'ery, T.; Peng, J.; Ramanathan, Y.; Marshall, N.; Marshall, T.; Amendt, B.; Mathews, M.B.; Price, D.H. Transcription elongation factor P-TEFb is required for HIV-1 tat transactivation in vitro. Genes Dev. 1997, 11, 2622-2632. [CrossRef] [PubMed]

87. Yankulov, K.; Bentley, D. Transcriptional control: Tat cofactors and transcriptional elongation. Curr. Biol. 1998, 8, R447-R449. [CrossRef]

88. Zhou, Q.; Chen, D.; Pierstorff, E.; Luo, K. Transcription elongation factor P-TEFb mediates Tat activation of HIV-1 transcription at multiple stages. EMBO J. 1998, 17, 3681-3691. [CrossRef] [PubMed]

89. Schulte, A.; Czudnochowski, N.; Barboric, M.; Schönichen, A.; Blazek, D.; Peterlin, B.M.; Geyer, M. Identification of a Cyclin T-Binding Domain in Hexim1 and Biochemical Analysis of Its Binding Competition with HIV-1 Tat. J. Biol. Chem. 2005, 280, 24968-24977. [CrossRef] [PubMed]

90. Barboric, M.; Yik, J.H.N.; Czudnochowski, N.; Yang, Z.; Chen, R.; Contreras, X.; Geyer, M.; Matija Peterlin, B.; Zhou, Q. Tat competes with HEXIM1 to increase the active pool of P-TEFb for HIV-1 transcription. Nucleic Acids Res. 2007, 35, 2003-2012. [CrossRef]

91. Karn, J. The molecular biology of HIV latency: Breaking and restoring the Tat-dependent transcriptional circuit. Curr. Opin. HIV AIDS 2011, 6, 4-11. [CrossRef]

92. Kamori, D.; Ueno, T. HIV-1 Tat and Viral Latency: What We Can Learn from Naturally Occurring Sequence Variations. Front. Microbiol. 2017, 8, 80. [CrossRef]

93. Donahue, D.A.; Kuhl, B.D.; Sloan, R.D.; Wainberg, M.A. The Viral Protein Tat Can Inhibit the Establishment of HIV-1 Latency. J. Virol. 2012, 86, 3253-3263. [CrossRef]

94. Khoury, G.; Mota, T.M.; Li, S.; Tumpach, C.; Lee, M.Y.; Jacobson, J.; Harty, L.; Anderson, J.L.; Lewin, S.R.; Purcell, D.F.J. HIV latency reversing agents act through Tat post translational modifications. Retrovirology 2018, 15, 36. [CrossRef]

95. Huang, H.; Zhou, Z.-H.; Adhikari, R.; Yamada, K.M.; Dhawan, S. Defective iron homeostasis in human immunodeficiency virus type-1 latency. Curr. Trends Immunol. 2016, 17, 125-131. [PubMed]

96. Shankaran, P.; Madlenakova, M.; Hajkova, V.; Jilich, D.; Svobodova, I.; Horinek, A.; Fujikura, Y.; Melkova, Z. Effects of Heme degradation products on reactivation of latent HIV-1. Acta Virol. 2017, 61, 86-96. [CrossRef] [PubMed]

97. McCall, K.A.; Huang, C.; Fierke, C.A. Function and Mechanism of Zinc Metalloenzymes. J. Nutr. 2000, 130, 1437S-1446S. [CrossRef] [PubMed] 
98. Maret, W. Zinc biochemistry: From a single zinc enzyme to a key element of life. Adv. Nutr. 2013, 4, 82-91. [CrossRef] [PubMed]

99. Kaur, K.; Gupta, R.; Saraf, S.A.; Saraf, S.K. Zinc: The Metal of Life. Compr. Rev. Food Sci. Food Saf. 2014, 13, 358-376. [CrossRef]

100. Jacob, C.; Maret, W.; Vallee, B.L. Control of zinc transfer between thionein, metallothionein, and zinc proteins. Proc. Natl. Acad. Sci. USA 1998, 95, 3489-3494. [CrossRef]

101. Frederickson, C.J.; Suh, S.W.; Silva, D.; Frederickson, C.J.; Thompson, R.B. Importance of Zinc in the Central Nervous System: The Zinc-Containing Neuron. J. Nutr. 2000, 130, 1471S-1483S. [CrossRef]

102. Hirano, T.; Murakami, M.; Fukada, T.; Nishida, K.; Yamasaki, S.; Suzuki, T. Roles of Zinc and Zinc Signaling in Immunity: Zinc as an Intracellular Signaling Molecule. Adv. Immunol. 2008, 97, 149-176.

103. Hojyo, S.; Fukada, T. Roles of Zinc Signaling in the Immune System. J. Immunol. Res. 2016, $2016,21$. [CrossRef]

104. Sprietsma, J.E. Zinc-controlled Th1/Th2 switch significantly determines development of diseases. Med. Hypotheses 1997, 49, 1-14. [CrossRef]

105. Subramanian Vignesh, K.; Landero Figueroa, J.A.; Porollo, A.; Caruso, J.A.; Deepe, G.S., Jr. Zinc sequestration: Arming phagocyte defense against fungal attack. PLoS Pathog. 2013, 9, e1003815.

106. Subramanian Vignesh, K.; Deepe, G.S. Immunological orchestration of zinc homeostasis: The battle between host mechanisms and pathogen defenses. Arch. Biochem. Biophys. 2016, 611, 66-78. [CrossRef]

107. Djoko, K.Y.; Ong, C.-L.Y.; Walker, M.J.; McEwan, A.G. The Role of Copper and Zinc Toxicity in Innate Immune Defense against Bacterial Pathogens. J. Biol. Chem. 2015, 290, 18954-18961. [CrossRef] [PubMed]

108. Takihara, H.; Cosentino, M.J.; Cockett, A.T.K. Zinc sulfate therapy for infertile male with or without varicocelectomy. Urology 1987, 29, 638-641. [CrossRef]

109. Yakoob, M.Y.; Theodoratou, E.; Jabeen, A.; Imdad, A.; Eisele, T.P.; Ferguson, J.; Jhass, A.; Rudan, I.; Campbell, H.; Black, R.E.; et al. Preventive zinc supplementation in developing countries: Impact on mortality and morbidity due to diarrhea, pneumonia and malaria. BMC Public Health 2011, 11, S23. [CrossRef] [PubMed]

110. Prasad, A.S. Discovery of Human Zinc Deficiency: Its Impact on Human Health and Disease. Adv. Nutr. 2013, 4, 176-190. [CrossRef] [PubMed]

111. Skrovanek, S.; DiGuilio, K.; Bailey, R.; Huntington, W.; Urbas, R.; Mayilvaganan, B.; Mercogliano, G.; Mullin, J.M. Zinc and gastrointestinal disease. World J. Gastrointest Pathophysiol. 2014, 5, 496-513. [CrossRef]

112. Livingstone, C. Zinc. Nutr. Clin. Pract. 2015, 30, 371-382.

113. Sprietsma, J. Zinkdeficiëntie predisponeert tot wel of niet virusgeinduceerde (auto-) immuunziekten zoals AIDS en kanker.'Zinc deficiency predisposes to (auto) immune diseases, whether or not virus-induced, such as AIDS and cancer. Tijdschrift Integrale Geneeskunde 1993, 9, 253-273.

114. Sprietsma, J. Nutriënten in AIDS-therapie [Nutrients in AIDS therapy]. Orthomoleculair 1993, 11, 72-79.

115. Mocchegiani, E.; Veccia, S.; Ancarani, F.; Scalise, G.; Fabris, N. Benefit of oral zinc supplementation as an adjunct to zidovudine (AZT) therapy against opportunistic infections in aids. Int. J. Immunopharmacol. 1995, 17, 719-727. [CrossRef]

116. Baum, M.K.; Shor-Posner, G.; Campa, A. Zinc Status in Human Immunodeficiency Virus Infection. J. Nutr. 2000, 130, 1421S-1423S. [CrossRef] [PubMed]

117. Wellinghausen, N.; Kern, W.V.; Jöchle, W.; Kern, P. Zinc serum level in human immunodeficiency virus-infected patients in relation to immunological status. Biol. Trace. Elem. Res. 2000, 73, 139-149. [CrossRef]

118. Odeh, M. The role of zinc in acquired immunodeficiency syndrome. J. Intern Med. 1992, 231, $463-469$. [CrossRef]

119. Falutz, J.; Tsoukas, C.; Gold, P. Zinc as a Cofactor in Human Immunodeficiency Virus-Induced Immunosuppression. JAMA 1988, 259, 2850-2851. [CrossRef]

120. Graham, N.; Sorensen, D.; Odaka, N.; Brookmeyer, R.; Chan, D.; Willett, W.C.; Morris, J.S.; Saah, A.J. Relationship of serum copper and zinc levels to HIV-1 seropositivity and progression to AIDS. J. Acquir. Immune. Defic. Syndr. 1991, 4, 976-980.

121. Baum, M.K.; Shor-Posner, G.; Lu, Y.; Rosner, B.; Sauberlich, H.E.; Fletcher, M.A.; Szapocznik, J.; Eisdorfer, C.; Buring, J.E.; Hennekens, C.H. Micronutrients and HIV-1 disease progression. AIDS 1995, 9, 1051-1056. [CrossRef] 
122. Baum, M.K.; Shor-Posner, G.; Lai, S.; Zhang, G.; Lai, H.; Fletcher, M.A.; Sauberlich, H.; Page, J.B. High Risk of HIV-Related Mortality Is Associated With Selenium Deficiency. J. Acquir. Immune. Defic. Syndr. 1997, 15, 370-374. [CrossRef]

123. Beutler, B.; Cerami, A. Cachectin: More Than a Tumor Necrosis Factor. N. Engl. J. Med. 1987, 316, $379-385$. [CrossRef]

124. Flieger, D.; Riethmüller, G.; Ziegler-Heitbrock, H. $\mathrm{Zn}^{2+}$ inhibits both tumor necrosis factor-mediated DNA fragmentation and cytolysis. Int. J. Cancer 1989, 44, 315-319. [CrossRef]

125. Rosenberg, Z.F.; Fauci, A.S. Immunopathogenic mechanisms of HIV infection. Clin. Immunol. Immunopathol. 1989, 50, S149-S156. [CrossRef]

126. Dowd, P.S.; Kelleher, J.; Guillou, P. T-lymphocyte subsets and interleukin-2 production in zinc-deficient rats. Br. J. Nutr. 1986, 55, 59-69. [CrossRef] [PubMed]

127. Hart, P.H.; Vitti, G.F.; Burgess, D.R.; Whitty, G.A.; Piccoli, D.S.; Hamilton, J.A. Potential antiinflammatory effects of interleukin 4: Suppression of human monocyte tumor necrosis factor alpha, interleukin 1, and prostaglandin E2. Proc. Natl. Acad. Sci. USA 1989, 86, 3803-3807. [CrossRef] [PubMed]

128. Rosenberg, Z.F.; Fauci, A.S. Immunopathogenic mechanisms of HIV infection: Cytokine induction of HIV expression. Immunol. Today 1990, 11, 176-180. [CrossRef]

129. Favier, A.; Sappey, C.; Leclerc, P.; Faure, P.; Micoud, M. Antioxidant status and lipid peroxidation in patients infected with HIV. Chem. Biol. Interact. 1994, 91, 165-180. [CrossRef]

130. Ivanov, A.V.; Valuev-Elliston, V.T.; Ivanova, O.N.; Kochetkov, S.N.; Starodubova, E.S.; Bartosch, B.; Isaguliants, M.G. Oxidative Stress during HIV Infection: Mechanisms and Consequences. Oxid. Med. Cell Longev. 2016, 2016, 8910396. [CrossRef]

131. Edeas, M.A.; Peltier, E.; Claise, C.; Khalfoun, Y.; Lindenbaum, A. Immunocytochemical study of uptake of exogenous carrier-free copper-zinc superoxide dismutase by peripheral blood lymphocytes. Cell. Mol. Biol. (Noisy-le-grand) 1996, 42, 1137-1143.

132. Zheng, R.; Jenkins, T.M.; Craigie, R. Zinc folds the N-terminal domain of HIV-1 integrase, promotes multimerization, and enhances catalytic activity. Proc. Natl. Acad. Sci. USA 1996, 93, 13659-13664. [CrossRef]

133. Cai, M.; Zheng, R.; Caffrey, M.; Craigie, R.; Clore, G.M.; Gronenborn, A.M. Solution structure of the N-terminal zinc binding domain of HIV-1 integrase. Nat. Struct. Biol. 1997, 4, 567-577. [CrossRef]

134. Lee, S.P.; Xiao, J.; Knutson, J.R.; Lewis, M.S.; Han, M.K. $\mathrm{Zn}^{2+}$ Promotes the Self-Association of Human Immunodeficiency Virus Type-1 Integrase in Vitro. Biochemistry 1997, 36, 173-180. [CrossRef]

135. Asante-Appiah, E.; Skalka, A.M. HIV-1 Integrase: Structural Organization, Conformational Changes, and Catalysis. Adv. Virus Res. 1999, 52, 351-369. [PubMed]

136. Dorfman, T.; Luban, J.; Goff, S.P.; Haseltine, W.A.; Göttlinger, H.G. Mapping of functionally important residues of a cysteine-histidine box in the human immunodeficiency virus type 1 nucleocapsid protein. J. Virol. 1993, 67, 6159-6169. [CrossRef] [PubMed]

137. Buckman, J.S.; Bosche, W.J.; Gorelick, R.J. Human Immunodeficiency Virus Type 1 Nucleocapsid Zn²+ Fingers Are Required for Efficient Reverse Transcription, Initial Integration Processes, and Protection of Newly Synthesized Viral DNA. J. Virol. 2003, 77, 1469-1480. [CrossRef] [PubMed]

138. Lee, N.; Gorelick, R.J.; Musier-Forsyth, K. Zinc finger-dependent HIV-1 nucleocapsid protein-TAR RNA interactions. Nucleic Acids Res. 2003, 31, 4847-4855. [CrossRef]

139. Grigorov, B.; Décimo, D.; Smagulova, F.; Péchoux, C.; Mougel, M.; Muriaux, D.; Darlix, J.-L. Intracellular HIV-1 Gag localization is impaired by mutations in the nucleocapsid zinc fingers. Retrovirology 2007, 4, 54. [CrossRef]

140. Mujeeb, A.; Ulyanov, N.B.; Georgantis, S.; Smirnov, I.; Chung, J.; Parslow, T.G.; James, T.L. Nucleocapsid protein-mediated maturation of dimer initiation complex of full-length SL1 stemloop of HIV-1: Sequence effects and mechanism of RNA refolding. Nucleic Acids Res. 2007, 35, 2026-2034. [CrossRef]

141. Ali, L.M.; Rizvi, T.A.; Mustafa, F. Cross- and Co-Packaging of Retroviral RNAs and Their Consequences. Viruses 2016, 8, 276. [CrossRef]

142. Lingappa, J.R.; Dooher, J.E.; Newman, M.A.; Kiser, P.K.; Klein, K.C. Basic Residues in the Nucleocapsid Domain of Gag Are Required for Interaction of HIV-1 Gag with ABCE1 (HP68), a Cellular Protein Important for HIV-1 Capsid Assembly. J. Biol. Chem. 2006, 281, 3773-3784. [CrossRef] 
143. Dussupt, V.; Javid, M.P.; Abou-Jaoudé, G.; Jadwin, J.A.; de La Cruz, J.; Nagashima, K.; Bouamr, F. The Nucleocapsid Region of HIV-1 Gag Cooperates with the PTAP and LYPXnL Late Domains to Recruit the Cellular Machinery Necessary for Viral Budding. PLoS Pathog. 2009, 5, e1000339. [CrossRef]

144. Muriaux, D.; Darlix, J.-L. Properties and functions of the nucleocapsid protein in virus assembly. RNA Biol. 2010, 7, 744-753. [CrossRef]

145. Rice, A.P.; Carlotti, F. Mutational analysis of the conserved cysteine-rich region of the human immunodeficiency virus type 1 Tat protein. J. Virol. 1990, 64, 1864-1868. [CrossRef] [PubMed]

146. Fridell, R.A.; Harding, L.S.; Bogerd, H.P.; Cullen, B.R. Identification of a Novel Human Zinc Finger Protein That Specifically Interacts with the Activation Domain of Lentiviral Tat Proteins. Virology 1995, 209, 347-357. [CrossRef] [PubMed]

147. Albini, A.; Benelli, R.; Giunciuglio, D.; Cai, T.; Mariani, G.; Ferrini, S.; Noonan, D.M. Identification of a Novel Domain of HIV Tat Involved in Monocyte Chemotaxis. J. Biol. Chem. 1998, 273, 15895-15900. [CrossRef] [PubMed]

148. Huang, H.-W.; Wang, K.-T. Structural Characterization of the Metal Binding Site in the Cysteine-Rich Region of HIV-1 Tat Protein. Biochem. Biophys. Res. Commun. 1996, 227, 615-621. [CrossRef]

149. Song, L.; Nath, A.; Geiger, J.D.; Moore, A.; Hochman, S. Human Immunodeficiency Virus Type 1 Tat Protein Directly Activates Neuronal N-methyl-D-aspartate Receptors at an Allosteric Zinc-Sensitive Site. J. Neurovirol. 2003, 9, 399-403. [CrossRef]

150. Egelé, C.; Barbier, P.; Didier, P.; Piémont, E.; Allegro, D.; Chaloin, O.; Muller, S.; Peyrot, V.; Mély, Y. Modulation of microtubule assembly by the HIV-1 Tat protein is strongly dependent on zinc binding to Tat. Retrovirology 2008, 5, 62. [CrossRef]

151. Chandra, T.; Maier, W.; König, H.G.; Hirzel, K.; Kögel, D.; Schüler, T.; Chandra, A.; Demirhan, I.; Laube, B. Molecular interactions of the type 1 human immunodeficiency virus transregulatory protein Tat with N-methyl-d-aspartate receptor subunits. Neuroscience 2005, 134, 145-153. [CrossRef]

152. Haughey, N.J.; Nath, A.; Mattson, M.P.; Slevin, J.T.; Geiger, J.D. HIV-1 Tat through phosphorylation of NMDA receptors potentiates glutamate excitotoxicity. J. Neurochem. 2001, 78, 457-467. [CrossRef]

153. Misumi, S.; Takamune, N.; Ohtsubo, Y.; Waniguchi, K.; Shoji, S. Zn ${ }^{2+}$ Binding to Cysteine-Rich Domain of Extracellular Human Immunodeficiency Virus Type 1 Tat Protein Is Associated with Tat Protein-Induced Apoptosis. AIDS Res. Hum. Retroviruses 2004, 20, 297-304. [CrossRef]

154. Luo, K.; Xiao, Z.; Ehrlich, E.; Yu, Y.; Liu, B.; Zheng, S.; Yu, X.-F. Primate lentiviral virion infectivity factors are substrate receptors that assemble with cullin 5-E3 ligase through a HCCH motif to suppress APOBEC3G. Proc. Natl. Acad. Sci. USA 2005, 102, 11444-11449. [CrossRef]

155. Wang, X.; Ao, Z.; Chen, L.; Kobinger, G.; Peng, J.; Yao, X. The Cellular Antiviral Protein APOBEC3G Interacts with HIV-1 Reverse Transcriptase and Inhibits Its Function during Viral Replication. J. Virol. 2012, 86, 3777-3786. [CrossRef] [PubMed]

156. Paul, I.; Cui, J.; Maynard, E.L. Zinc binding to the HCCH motif of HIV-1 virion infectivity factor induces a conformational change that mediates protein-protein interactions. Proc. Natl. Acad. Sci. USA 2006, 103, 18475-18480. [CrossRef] [PubMed]

157. Zhu, Y.; Gao, G. ZAP-mediated mRNA degradation. RNA Biol. 2008, 5, 65-67. [CrossRef] [PubMed]

158. Zhu, Y.; Chen, G.; Lv, F.; Wang, X.; Ji, X.; Xu, Y.; Sun, J.; Wu, L.; Zheng, Y.-T.; Gao, G. Zinc-finger antiviral protein inhibits HIV-1 infection by selectively targeting multiply spliced viral mRNAs for degradation. Proc. Natl. Acad. Sci. USA 2011, 108, 15834-15839. [CrossRef] [PubMed]

159. Zheng, X.; Wang, X.; Tu, F.; Wang, Q.; Fan, Z.; Gao, G. TRIM25 Is Required for the Antiviral Activity of Zinc Finger Antiviral Protein. J. Virol. 2017, 91, e00088-17. [CrossRef] [PubMed]

160. Cairo, G.; Bernuzzi, F; Recalcati, S. A precious metal: Iron, an essential nutrient for all cells. Genes Nutr. 2006, 1, 25-39. [CrossRef] [PubMed]

161. Dlouhy, A.C.; Outten, C.E. The iron metallome in eukaryotic organisms. Met. Ions Life Sci. 2013, 12, $241-278$.

162. Ganz, T. Molecular Control of Iron Transport. J. Am. Soc. Nephrol. 2007, 18, 394-400. [CrossRef]

163. Ganz, T. Systemic Iron Homeostasis. Physiol. Rev. 2013, 93, 1721-1741. [CrossRef]

164. Anderson, G.J.; Vulpe, C.D. The Cellular Physiology of Iron. In Iron Deficiency and Overload: From Basic Biology to Clinical Medicine; Yehuda, S., Mostofsky, D.I., Eds.; Humana Press: Totowa, NJ, USA, 2010; pp. 3-29.

165. Anderson, G.J.; Frazer, D.M. Current understanding of iron homeostasis. Am. J. Clin. Nutr. 2017, 106 (Suppl. 6), 1559S-1566S. [CrossRef] 
166. Sharp, P.; Srai, S.-K. Molecular mechanisms involved in intestinal iron absorption. World J. Gastroenterol. 2007, 13, 4716-4724. [CrossRef] [PubMed]

167. Graham, R.M.; Reutens, G.M.; Herbison, C.E.; Delima, R.D.; Chua, A.C.G.; Olynyk, J.K.; Trinder, D. Transferrin receptor 2 mediates uptake of transferrin-bound and non-transferrin-bound iron. J. Hepatol. 2008, 48, 327-334. [CrossRef] [PubMed]

168. Mayle, K.M.; Le, A.M.; Kamei, D.T. The intracellular trafficking pathway of transferrin. Biochim. Biophys. Acta 2012, 1820, 264-281. [CrossRef] [PubMed]

169. Cao, H.; Schroeder, B.; Chen, J.; Schott, M.B.; McNiven, M.A. The Endocytic Fate of the Transferrin Receptor Is Regulated by c-Abl Kinase. J. Biol. Chem. 2016, 291, 16424-16437. [CrossRef]

170. Fernández, B.; Fdez, E.; Gómez-Suaga, P.; Gil, F.; Molina-Villalba, I.; Ferrer, I.; Patel, S.; Churchill, G.C.; Hilfiker, $\mathrm{S}$. Iron overload causes endolysosomal deficits modulated by NAADP-regulated 2-pore channels and RAB7A. Autophagy 2016, 12, 1487-1506. [CrossRef]

171. Lambe, T.; Simpson, R.J.; Dawson, S.; Bouriez-Jones, T.; Crockford, T.L.; Lepherd, M.; Latunde-Dada, G.O.; Robinson, H.; Raja, K.B.; Campagna, D.R.; et al. Identification of a Steap3 endosomal targeting motif essential for normal iron metabolism. Blood 2009, 113, 1805-1808. [CrossRef]

172. Tabuchi, M.; Yoshimori, T.; Yamaguchi, K.; Yoshida, T.; Kishi, F. Human NRAMP2/DMT1, Which Mediates Iron Transport across Endosomal Membranes, Is Localized to Late Endosomes and Lysosomes in HEp-2 Cells. J. Biol. Chem. 2000, 275, 22220-22228. [CrossRef]

173. Dong, X.-P.; Cheng, X.; Mills, E.; Delling, M.; Wang, F.; Kurz, T.; Xu, H. The type IV mucolipidosis-associated protein TRPML1 is an endolysosomal iron release channel. Nature 2008, 455, 996. [CrossRef]

174. Winterbourn, C.C. Toxicity of iron and hydrogen peroxide: The Fenton reaction. Toxicol. Lett. 1995, 82-83, 969-974. [CrossRef]

175. Hemnani, T.; Parihar, M. Reactive oxygen species and oxidative DNA damage. Indian. J. Physiol. Pharmacol. 1998, 42, 440-452.

176. Cejas, P.; Casado, E.; Belda-Iniesta, C.; De Castro, J.; Espinosa, E.; Redondo, A.; Sereno, M.; García-Cabezas, M.Á.; Juan, A.F.V.; Domínguez-Cáceres, A.; et al. Implications of Oxidative Stress and Cell Membrane Lipid Peroxidation in Human Cancer (Spain). Cancer Causes Control 2004, 15, 707-719. [CrossRef] [PubMed]

177. Lei, P.; Bai, T.; Sun, Y. Mechanisms of Ferroptosis and Relations With Regulated Cell Death: A Review. Front. Physiol. 2019, 10. [CrossRef] [PubMed]

178. Stoyanovsky, D.A.; Tyurina, Y.Y.; Shrivastava, I.; Bahar, I.; Tyurin, V.A.; Protchenko, O.; Jadhav, S.; Bolevich, S.B.; Kozlov, A.V.; Vladimirov, Y.A.; et al. Iron catalysis of lipid peroxidation in ferroptosis: Regulated enzymatic or random free radical reaction? Free Radic. Biol. Med. 2019, 133, 153-161. [CrossRef] [PubMed]

179. Birben, E.; Sahiner, U.M.; Sackesen, C.; Erzurum, S.; Kalayci, O. Oxidative Stress and Antioxidant Defense. World Allergy Organ. J. 2012, 5, 9-19. [CrossRef]

180. Kurutas, E.B. The importance of antioxidants which play the role in cellular response against oxidative/nitrosative stress: Current state. Nutr. J. 2016, 15, 71. [CrossRef]

181. Drakesmith, H.; Prentice, A. Viral infection and iron metabolism. Nat. Rev. Microbiol. 2008, 6, 541-552. [CrossRef]

182. Nekhai, S.; Kumari, N.; Dhawan, S. Role of cellular iron and oxygen in the regulation of HIV-1 infection. Future Virol. 2013, 8, 301-311. [CrossRef]

183. Boelaert, J.R.; Weinberg, G.A.; Weinberg, E.D. Altered iron metabolism in HIV infection: Mechanisms, possible consequences, and proposals for management. Infect. Agents Dis. 1996, 5, 36-46.

184. Gordeuk, V.R.; Delanghe, J.R.; Langlois, M.R.; Boelaert, J.R. Iron status and the outcome of HIV infection: An overview. J. Clin. Virol. 2001, 20, 111-115. [CrossRef]

185. Drakesmith, H.; Chen, N.; Ledermann, H.; Screaton, G.; Townsend, A.; Xu, X.-N. HIV-1 Nef down-regulates the hemochromatosis protein HFE, manipulating cellular iron homeostasis. Proc. Natl. Acad. Sci. USA 2005, 102, 11017-11022. [CrossRef]

186. Rawat, R.; Humphrey, J.H.; Ntozini, R.; Mutasa, K.; Iliff, P.J.; Stoltzfus, R.J. Elevated iron stores are associated with HIV disease severity and mortality among postpartum women in Zimbabwe. Public Health Nutr. 2009, 12, 1321-1329. [CrossRef] [PubMed] 
187. McDermid, J.M.; Jaye, A.; Schim van der Loeff, M.F.; Todd, J.; Bates, C.; Austin, S.; Jeffries, D.; Awasana, A.A.; Whittle, H.C.; Prentice, A.M. Elevated Iron Status Strongly Predicts Mortality in West African Adults With HIV Infection. J. Acquir. Immune Defic. Syndr. 2007, 46, 498-507. [CrossRef] [PubMed]

188. Barthelme, D.; Scheele, U.; Dinkelaker, S.; Janoschka, A.; MacMillan, F.; Albers, S.-V.; Driessen, A.J.M.; Stagni, M.S.; Bill, E.; Meyer-Klaucke, W.; et al. Structural Organization of Essential Iron-Sulfur Clusters in the Evolutionarily Highly Conserved ATP-binding Cassette Protein ABCE1. J. Biol. Chem. 2007, 282, 14598-14607. [CrossRef] [PubMed]

189. Zimmerman, C.; Klein, K.C.; Kiser, P.K.; Singh, A.R.; Firestein, B.L.; Riba, S.C.; Lingappa, J.R. Identification of a host protein essential for assembly of immature HIV-1 capsids. Nature 2002, 415, 88-92. [CrossRef] [PubMed]

190. Schatz, O.; Oft, M.; Dascher, C.; Schebesta, M.; Rosorius, O.; Jaksche, H.; Dobrovnik, M.; Bevec, D.; Hauber, J. Interaction of the HIV-1 Rev cofactor eukaryotic initiation factor 5A with ribosomal protein L5. Proc. Natl. Acad. Sci. USA 1998, 95, 1607-1612. [CrossRef] [PubMed]

191. Modem, S.; Thipparthi, R.R. Cellular Proteins and HIV-1 Rev Function. Curr. HIV Res. 2009, 7, 91-100.

192. Liu, J.; Henao-Mejia, J.; Liu, H.; Zhao, Y.; He, J.J. Translational Regulation of HIV-1 Replication by HIV-1 Rev Cellular Cofactors Sam68, eIF5A, hRIP, and DDX3. J. Neuroimmune Pharmacol. 2011, 6, 308-321. [CrossRef]

193. Hoque, M.; Hanauske-Abel, H.M.; Palumbo, P.; Saxena, D.; D'Alliessi Gandolfi, D.; Park, M.H.; Pe'ery, T.; Mathews, M.B. Inhibition of HIV-1 gene expression by Ciclopirox and Deferiprone, drugs that prevent hypusination of eukaryotic initiation factor 5A. Retrovirology 2009, 6, 90. [CrossRef]

194. Sattentau, Q.J.; Stevenson, M. Macrophages and HIV-1: An Unhealthy Constellation. Cell Host Microbe. 2016, 19, 304-310. [CrossRef]

195. Knutson, M.D.; Oukka, M.; Koss, L.M.; Aydemir, F.; Wessling-Resnick, M. Iron release from macrophages after erythrophagocytosis is up-regulated by ferroportin 1 overexpression and down-regulated by hepcidin. Proc. Natl. Acad. Sci. USA 2005, 102, 1324-1328. [CrossRef]

196. Beaumont, C. Multiple regulatory mechanisms act in concert to control ferroportin expression and heme iron recycling by macrophages. Haematologica 2010, 95, 1233-1236. [CrossRef] [PubMed]

197. Finn, A.V.; Nakano, M.; Polavarapu, R.; Karmali, V.; Saeed, O.; Zhao, X.; Yazdani, S.; Otsuka, F.; Davis, T.; Habib, A.; et al. Hemoglobin Directs Macrophage Differentiation and Prevents Foam Cell Formation in Human Atherosclerotic Plaques. J. Am. Coll. Cardiol. 2012, 59, 166-177. [CrossRef] [PubMed]

198. Schimanski, L.M.; Drakesmith, H.; Merryweather-Clarke, A.T.; Viprakasit, V.; Edwards, J.P.; Sweetland, E.; Bastin, J.M.; Cowley, D.; Chinthammitr, Y.; Robson, K.J.H.; et al. In vitro functional analysis of human ferroportin (FPN) and hemochromatosis-associated FPN mutations. Blood 2005, 105, 4096-4102. [CrossRef] [PubMed]

199. Xu, M.; Kashanchi, F.; Foster, A.; Rotimi, J.; Turner, W.; Gordeuk, V.R.; Nekhai, S. Hepcidin induces HIV-1 transcription inhibited by ferroportin. Retrovirology 2010, 7, 104. [CrossRef]

200. Jison, M.L.; Munson, P.J.; Barb, J.J.; Suffredini, A.F.; Talwar, S.; Logun, C.; Raghavachari, N.; Beigel, J.H.; Shelhamer, J.H.; Danner, R.L.; et al. Blood mononuclear cell gene expression profiles characterize the oxidant, hemolytic, and inflammatory stress of sickle cell disease. Blood 2004, 104, 270-280. [CrossRef]

201. Kroot, J.J.C.; Laarakkers, C.M.M.; Kemna, E.H.J.M.; Biemond, B.J.; Swinkels, D.W. Regulation of serum hepcidin levels in sickle cell disease. Haematologica 2009, 94, 885-887. [CrossRef]

202. Bagasra, O.; Steiner, R.M.; Ballas, S.K.; Castro, O.; Dornadula, G.; Embury, S.; Jungkind, D.; Bobroski, L.; Kutlar, A.; Burchott, S. Viral Burden and Disease Progression in HIV-1-Infected Patients with Sickle Cell Anemia. Am. J. Hematol. 1998, 59, 199-207. [CrossRef]

203. Nouraie, M.; Nekhai, S.; Gordeuk, V.R. Sickle cell disease is associated with decreased HIV but higher HBV and HCV comorbidities in US hospital discharge records: A cross-sectional study. Sex Transm. Infect. 2012, 88, 528-533. [CrossRef]

204. Taylor VI, J.G.; Ackah, D.; Cobb, C.; Orr, N.; Percy, M.J.; Sachdev, V.; Machado, R.; Castro, O.; Kato, G.J.; Chanock, S.J.; et al. Mutations and polymorphisms in hemoglobin genes and the risk of pulmonary hypertension and death in sickle cell disease. Am. J. Hematol. 2008, 83, 6-14. [CrossRef]

205. Ferreira, A.; Marguti, I.; Bechmann, I.; Jeney, V.; Chora, Â.; Palha, N.R.; Rebelo, S.; Henri, A.; Beuzard, Y.; Soares, M.P. Sickle Hemoglobin Confers Tolerance to Plasmodium Infection. Cell 2011, 145, 398-409. [CrossRef] 
206. Debebe, Z.; Ammosova, T.; Jerebtsova, M.; Kurantsin-Mills, J.; Niu, X.; Charles, S.; Richardson, D.R.; Ray, P.E.; Gordeuk, V.R.; Nekhai, S. Iron chelators ICL670 and 311 inhibit HIV-1 transcription. Virology 2007, 367, 324-333. [CrossRef] [PubMed]

207. Debebe, Z.; Ammosova, T.; Breuer, D.; Lovejoy, D.B.; Kalinowski, D.S.; Karla, P.K.; Kumar, K.; Jerebtsova, M.; Ray, P.; Kashanchi, F.; et al. Iron Chelators of the Di-2-pyridylketone Thiosemicarbazone and 2-Benzoylpyridine Thiosemicarbazone Series Inhibit HIV-1 Transcription: Identification of Novel Cellular Targets-Iron, Cyclin-Dependent Kinase (CDK) 2, and CDK9. Mol. Pharmacol. 2011, 79, 185-196. [CrossRef] [PubMed]

208. St., Gelais, C.; de Silva, S.; Hach, J.C.; White, T.E.; Diaz-Griffero, F.; Yount, J.S.; Wu, L. Identification of Cellular Proteins Interacting with the Retroviral Restriction Factor SAMHD1. J. Virol. 2014, 88, 5834-5844. [CrossRef] [PubMed]

209. Goldstone, D.C.; Ennis-Adeniran, V.; Hedden, J.J.; Groom, H.C.T.; Rice, G.I.; Christodoulou, E.; Walker, P.A.; Kelly, G.; Haire, L.F.; Yap, M.W.; et al. HIV-1 restriction factor SAMHD1 is a deoxynucleoside triphosphate triphosphohydrolase. Nature 2011, 480, 379-382. [CrossRef] [PubMed]

210. Laguette, N.; Sobhian, B.; Casartelli, N.; Ringeard, M.; Chable-Bessia, C.; Ségéral, E.; Yatim, A.; Emiliani, S.; Schwartz, O.; Benkirane, M. SAMHD1 is the dendritic- and myeloid-cell-specific HIV-1 restriction factor counteracted by Vpx. Nature 2011, 474, 654-657. [CrossRef] [PubMed]

211. Chen, H.; Li, C.; Huang, J.; Cung, T.; Seiss, K.; Beamon, J.; Carrington, M.F.; Porter, L.C.; Burke, P.S.; Yang, Y.; et al. CD4+ T cells from elite controllers resist HIV-1 infection by selective upregulation of p21. J. Clin. Investig. 2011, 121, 1549-1560. [CrossRef] [PubMed]

212. Choi, B.H.; Kim, C.G.; Bae, Y.-S.; Lim, Y.; Lee, Y.H.; Shin, S.Y. p21 Waf1/Cip1 Expression by Curcumin in U-87MG Human Glioma Cells: Role of Early Growth Response-1 Expression. Cancer Res. 2008, 68, 1369-1377. [CrossRef]

213. Saletta, F.; Suryo Rahmanto, Y.; Noulsri, E.; Richardson, D.R. Iron Chelator-Mediated Alterations in Gene Expression: Identification of Novel Iron-Regulated Molecules That Are Molecular Targets of Hypoxia-Inducible Factor-1 $\alpha$ and p53. Mol. Pharmacol. 2010, 77, 443-458. [CrossRef]

214. Kaul, D.K.; Fabry, M.E.; Suzuka, S.M.; Zhang, X. Antisickling fetal hemoglobin reduces hypoxia-inducible factor- $1 \alpha$ expression in normoxic sickle mice: Microvascular implications. Am. J. Physiol. Heart Circ. Physiol. 2013, 304, H42-H50. [CrossRef]

215. Devadas, K.; Dhawan, S. Hemin Activation Ameliorates HIV-1 Infection via Heme Oxygenase-1 Induction. J. Immunol. 2006, 176, 4252-4257. [CrossRef]

216. Devadas, K.; Hewlett, I.K.; Dhawan, S. Lipopolysaccharide suppresses HIV-1 replication in human monocytes by protein kinase C-dependent heme oxygenase-1 induction. J. Leukoc. Biol. 2010, 87, 915-924. [CrossRef] [PubMed]

217. Kumari, N.; Ammosova, T.; Diaz, S.; Lin, X.; Niu, X.; Ivanov, A.; Jerebtsova, M.; Dhawan, S.; Oneal, P.; Nekhai, S. Increased iron export by ferroportin induces restriction of HIV-1 infection in sickle cell disease. Blood Adv. 2016, 1, 170-183. [CrossRef]

218. Berra, E.; Benizri, E.; Ginouvès, A.; Volmat, V.; Roux, D.; Pouysségur, J. HIF prolyl-hydroxylase 2 is the key oxygen sensor setting low steady-state levels of HIF-1alpha in normoxia. EMBO J. 2003, 22, 4082-4090. [CrossRef] [PubMed]

219. Lin, X.; Ammosova, T.; Kumari, N.; Nekhai, S. Protein Phosphatase-1-targeted Small Molecules, Iron Chelators and Curcumin Analogs as HIV-1 Antivirals. Curr. Pharm. Des. 2017, 23, 4122-4132. [CrossRef] [PubMed]

220. Chen, R.; Liu, M.; Li, H.; Xue, Y.; Ramey, W.N.; He, N.; Ai, N.; Luo, H.; Zhu, Y.; Zhou, N.; et al. PP2B and $\mathrm{PP} 1 \alpha$ cooperatively disrupt 7SK snRNP to release $\mathrm{P}-\mathrm{TEFb}$ for transcription in response to $\mathrm{Ca}^{2+}$ signaling. Genes Dev. 2008, 22, 1356-1368. [CrossRef]

221. Ammosova, T.; Obukhov, Y.; Kotelkin, A.; Breuer, D.; Beullens, M.; Gordeuk, V.R.; Bollen, M.; Nekhai, S. Protein phosphatase-1 activates CDK9 by dephosphorylating Ser175. PLoS ONE 2011, 6, e18985. [CrossRef]

222. Taylor, C.T.; Furuta, G.T.; Synnestvedt, K.; Colgan, S.P. Phosphorylation-dependent targeting of cAMP response element binding protein to the ubiquitin/proteasome pathway in hypoxia. Proc. Natl. Acad. Sci. USA 2000, 97, 12091-12096. [CrossRef] 
223. Comerford, K.M.; Leonard, M.O.; Cummins, E.P.; Fitzgerald, K.T.; Beullens, M.; Bollen, M.; Taylor, C.T. Regulation of protein phosphatase $1 \gamma$ activity in hypoxia through increased interaction with NIPP1: Implications for cellular metabolism. J. Cell. Physiol. 2006, 209, 211-218. [CrossRef]

224. Ammosova, T.; Yedavalli, V.R.; Niu, X.; Jerebtsova, M.; Van Eynde, A.; Beullens, M.; Bollen, M.; Jeang, K.-T.; Nekhai, S. Expression of a protein phosphatase 1 inhibitor, cdNIPP1, increases CDK9 threonine 186 phosphorylation and inhibits HIV-1 transcription. J. Biol. Chem. 2011, 286, 3798-3804. [CrossRef]

225. Nekhai, S.; Jerebtsova, M.; Jackson, A.; Southerland, W. Regulation of HIV-1 transcription by protein phosphatase 1. Curr. HIV Res. 2007, 5, 3-9.

226. Tabor, E.; Epstein, J.; Hewlett, I.; Lee, S. Inhibition by desferrioxamine of in-vitro replication of HIV-1. Lancet 1991, 337, 795. [CrossRef]

227. Van Asbeck, B.S.; Georgiou, N.A.; van der Bruggen, T.; Oudshoorn, M.; Nottet, H.S.L.M.; Marx, J.J.M. Anti-HIV effect of iron chelators: Different mechanisms involved. J. Clin. Virol. 2001, 20, 141-147. [CrossRef]

228. Ammosova, T.; Berro, R.; Kashanchi, F.; Nekhai, S. RNA interference directed to CDK2 inhibits HIV-1 transcription. Virology 2005, 341, 171-178. [CrossRef] [PubMed]

229. Guendel, I.; Carpio, L.; Easley, R.; Van Duyne, R.; Coley, W.; Agbottah, E.; Dowd, C.; Kashanchi, F.; Kehn-Hall, K. 9-aminoacridine Inhibition of HIV-1 Tat Dependent Transcription. Virol. J. 2009, 6, 114. [CrossRef] [PubMed]

230. Coulonval, K.; Bockstaele, L.; Paternot, S.; Roger, P.P. Phosphorylations of Cyclin-dependent Kinase 2 Revisited Using Two-dimensional Gel Electrophoresis. J. Biol. Chem. 2003, 278, 52052-52060. [CrossRef] [PubMed]

231. Herbeck, J.; Ghorai, S.; Chen, L.; Rinaldo, C.R.; Margolick, J.B.; Detels, R.; Jacobson, L.; Wolinsky, S.; Mullins, J.I. p21WAF1/CIP1 RNA Expression in Highly HIV-1 Exposed, Uninfected Individuals. PLoS ONE 2015, 10, e0119218. [CrossRef] [PubMed]

232. Wu, W.; Kehn-Hall, K.; Pedati, C.; Zweier, L.; Castro, I.; Klase, Z.; Dowd, C.S.; Dubrovsky, L.; Bukrinsky, M.; Kashanchi, F. Drug 9AA reactivates p21/Waf1 and Inhibits HIV-1 progeny formation. Virol. J. 2008, 5, 41. [CrossRef]

233. Sáez-Cirión, A.; Hamimi, C.; Bergamaschi, A.; David, A.; Versmisse, P.; Mélard, A.; Boufassa, F.; Barré-Sinoussi, F.; Lambotte, O.; Rouzioux, C.; et al. Restriction of HIV-1 replication in macrophages and CD4+ T cells from HIV controllers. Blood 2011, 118, 955-964. [CrossRef]

234. Kashanchi, F.; Agbottah, E.T.; Pise-Masison, C.A.; Mahieux, R.; Duvall, J.; Kumar, A.; Brady, J.N. Cell cycle-regulated transcription by the human immunodeficiency virus type 1 Tat transactivator. J. Virol. 2000, 74, 652-660. [CrossRef]

235. Deng, L.; Ammosova, T.; Pumfery, A.; Kashanchi, F.; Nekhai, S. HIV-1 Tat Interaction with RNA Polymerase II C-terminal Domain (CTD) and a Dynamic Association with CDK2 Induce CTD Phosphorylation and Transcription from HIV-1 Promoter. J. Biol. Chem. 2002, 277, 33922-33929. [CrossRef]

236. Nekhai, S.; Zhou, M.; Fernandez, A.; Lane, W.S.; Lamb, N.J.; Brady, J.; Kumar, A. HIV-1 Tat-associated RNA polymerase C-terminal domain kinase, CDK2, phosphorylates CDK7 and stimulates Tat-mediated transcription. Biochem. J. 2002, 364, 649-657. [CrossRef] [PubMed]

237. Wang, H.; Li, Z.; Niu, J.; Xu, Y.; Ma, L.; Lu, A.; Wang, X.; Qian, Z.; Huang, Z.; Jin, X.; et al. Antiviral effects of ferric ammonium citrate. Cell Discov. 2018, 4, 14. [CrossRef] [PubMed]

238. Malina, J.; Hannon, M.J.; Brabec, V. Iron(II) supramolecular helicates interfere with the HIV-1 Tat-TAR RNA interaction critical for viral replication. Sci. Rep. 2016, 6, 29674. [CrossRef] [PubMed]

239. Mancone, C.; Grimaldi, A.; Refolo, G.; Abbate, I.; Rozera, G.; Benelli, D.; Fimia, G.M.; Barnaba, V.; Tripodi, M.; Piacentini, M.; et al. Iron overload down-regulates the expression of the HIV-1 Rev cofactor eIF5A in infected T lymphocytes. Proteome Sci. 2017, 15, 18. [CrossRef]

240. Shytaj, I.; Lucic, B.; Forcato, M.; Billingsley, J.; Bosinger, S.; Stanic, M.; Gregoretti, F.; Antonelli, L.; Oliva, G.; Frese, C.; et al. Alterations of redox and iron metabolism accompany development of HIV latency. bioRxiv 2019, 11, e102209. [CrossRef]

241. Piette, J.; Legrand-Poels, S. HIV-1 reactivation after an oxidative stress mediated by different reactive oxygen species. Chem. Biol. Interact. 1994, 91, 79-89. [CrossRef]

242. Song, S.; Christova, T.; Perusini, S.; Alizadeh, S.; Bao, R.-Y.; Miller, B.W.; Hurren, R.; Jitkova, Y.; Gronda, M.; Isaac, M.; et al. Wnt Inhibitor Screen Reveals Iron Dependence of $\beta$-Catenin Signaling in Cancers. Cancer Res. 2011, 71, 7628-7639. [CrossRef] 
243. Coombs, G.S.; Schmitt, A.A.; Canning, C.A.; Alok, A.; Low, I.C.C.; Banerjee, N.; Kaur, S.; Utomo, V.; Jones, C.M.; Pervaiz, S.; et al. Modulation of Wnt/ $\beta$-catenin signaling and proliferation by a ferrous iron chelator with therapeutic efficacy in genetically engineered mouse models of cancer. Oncogene 2012, 31, 213-225. [CrossRef]

244. Holley, A.K.; Bakthavatchalu, V.; Velez-Roman, J.M.; St Clair, D.K. Manganese superoxide dismutase: Guardian of the powerhouse. Int. J. Mol. Sci. 2011, 12, 7114-7162. [CrossRef]

245. Miriyala, S.; Spasojevic, I.; Tovmasyan, A.; Salvemini, D.; Vujaskovic, Z.; St Clair, D.; Batinic-Haberle, I. Manganese superoxide dismutase, MnSOD and its mimics. Biochim. Biophys Acta 2012, 1822, 794-814. [CrossRef]

246. Baly, D.L.; Keen, C.L.; Hurley, L.S. Effects of manganese deficiency on pyruvate carboxylase and phosphoenolpyruvate carboxykinase activity and carbohydrate homeostasis in adult rats. Biol. Trace Elem. Res. 1986, 11, 201. [CrossRef] [PubMed]

247. Wedler, F.C.; Denman, R.B.; Roby, W.G. Glutamine synthetase from ovine brain is a manganese(II) enzyme. Biochemistry 1982, 21, 6389-6396. [CrossRef] [PubMed]

248. Sidoryk-Wegrzynowicz, M.; Aschner, M. Manganese toxicity in the central nervous system: The glutamine/glutamate- $\gamma$-aminobutyric acid cycle. J. Intern. Med. 2013, 273, 466-477. [CrossRef] [PubMed]

249. Li, L.; Yang, X. The Essential Element Manganese, Oxidative Stress, and Metabolic Diseases: Links and Interactions. Oxid. Med. Cell. Longev. 2018, 2018, 7580707. [CrossRef]

250. Raoul, H.; Mabondzo, A.; Le Naour, R.; Dormont, D. Effect of human immunodeficiency virus type 1 (HIV-1) monocyte-derived macrophages infection on the manganous superoxide dismutase gene expression. Chem. Biol. Interact. 1994, 91, 123-131. [CrossRef]

251. Raoul, H.; Naour, R.L.; Blond, D.; Dormont, D. HIV Type 1 Infection of Human Macrophages Induces an Upregulation of Manganese Superoxide Dismutase Gene That May Protect Cells from Death. AIDS Res. Hum. Retroviruses 1998, 14, 427-434. [CrossRef]

252. Sarafianos, S.G.; Marchand, B.; Das, K.; Himmel, D.M.; Parniak, M.A.; Hughes, S.H.; Arnold, E. Structure and Function of HIV-1 Reverse Transcriptase: Molecular Mechanisms of Polymerization and Inhibition. J. Mol. Biol. 2009, 385, 693-713. [CrossRef]

253. Huang, H.; Chopra, R.; Verdine, G.L.; Harrison, S.C. Structure of a Covalently Trapped Catalytic Complex of HIV-1 Reverse Transcriptase: Implications for Drug Resistance. Science 1998, 282, 1669-1675. [CrossRef]

254. Tian, L.; Kim, M.-S.; Li, H.; Wang, J.; Yang, W. Structure of HIV-1 reverse transcriptase cleaving RNA in an RNA/DNA hybrid. Proc. Natl. Acad. Sci. USA 2018, 115, 507-512. [CrossRef]

255. Cirino, N.M.; Cameron, C.E.; Smith, J.S.; Roth, M.J.; Benkovic, S.J.; Le Grice, S.F.J. Divalent cation modulation of the ribonuclease functions of human immunodeficiency virus reverse transcriptase. Biochemistry 1995, 34, 9936-9943. [CrossRef]

256. Klumpp, K.; Hang, J.Q.; Rajendran, S.; Yang, Y.; Derosier, A.; Wong Kai In, P.; Overton, H.; Parkes, K.E.B.; Cammack, N.; Martin, J.A. Two-metal ion mechanism of RNA cleavage by HIV RNase H and mechanism-based design of selective HIV RNase H inhibitors. Nucleic Acids Res. 2003, 31, 6852-6859. [CrossRef] [PubMed]

257. Ben-Artzi, H.; Zeelon, E.; Le-Grice, S.F.J.; Gorecki, M.; Panet, A. Characterization of the double stranded RNA dependent RNase activity associated with recombinant reverse transcriptases. Nucleic Acids Res. 1992, 20, 5115-5118. [CrossRef] [PubMed]

258. Goldschmidt, V.; Didierjean, J.; Ehresmann, B.; Ehresmann, C.; Isel, C.; Marquet, R. $\mathrm{Mg}^{2+}$ dependency of HIV-1 reverse transcription, inhibition by nucleoside analogues and resistance. Nucleic Acids Res. 2006, 34, 42-52. [CrossRef] [PubMed]

259. Schultz, S.J.; Champoux, J.J. RNase H activity: Structure, specificity, and function in reverse transcription. Virus Res. 2008, 134, 86-103. [CrossRef] [PubMed]

260. Vartanian, J.-P.; Sala, M.; Henry, M.; Wain-Hobson, S.; Meyerhans, A. Manganese cations increase the mutation rate of human immunodeficiency virus type 1 ex vivo. J. Gen. Virol. 1999, 80, 1983-1986. [CrossRef] [PubMed]

261. Fenstermacher, K.J.; DeStefano, J.J. Mechanism of HIV reverse transcriptase inhibition by zinc: Formation of a highly stable enzyme-(primer-template) complex with profoundly diminished catalytic activity. J. Biol. Chem. 2011, 286, 40433-40442. [CrossRef] [PubMed]

262. Delelis, O.; Carayon, K.; Saï, A.; Deprez, E.; Mouscadet, J.-F. Integrase and integration: Biochemical activities of HIV-1 integrase. Retrovirology 2008, 5, 114. [CrossRef] 
263. Craigie, R. The molecular biology of HIV integrase. Future Virol. 2012, 7, 679-686. [CrossRef]

264. Yi, J.; Asante-Appiah, E.; Skalka, A.M. Divalent Cations Stimulate Preferential Recognition of a Viral DNA End by HIV-1 Integrase. Biochemistry 1999, 38, 8458-8468. [CrossRef]

265. Thang, K.C.; David, R.D. Structure and Function of HIV-1 Integrase. Curr. Top. Med. Chem. 2004, 4, 965-977.

266. Asante-Appiah, E.; Seeholzer, S.H.; Skalka, A.M. Structural Determinants of Metal-induced Conformational Changes in HIV-1 Integrase. J. Biol. Chem. 1998, 273, 35078-35087. [CrossRef] [PubMed]

267. Tchertanov, L.; Mouscadet, J.-F. Target Recognition by Catechols and $\beta$-Ketoenols: Potential Contribution of Hydrogen Bonding and $\mathrm{Mn} / \mathrm{Mg}$ Chelation to HIV-1 Integrase Inhibition. J. Med. Chem. 2007, 50, 1133-1145. [CrossRef] [PubMed]

268. Barciela, J.; Latorre, C.; García-Martín, S.; Peña, R. A brief study of the role of Selenium as antioxidant. Elec. J. Environ. Agric. Food Chem. 2008, 7, 3151-3155.

269. Zoidis, E.; Seremelis, I.; Kontopoulos, N.; Danezis, G.P. Selenium-Dependent Antioxidant Enzymes: Actions and Properties of Selenoproteins. Antioxidants 2018, 7, 66. [CrossRef]

270. Arthur, J.R.; Nicol, F.; Beckett, G.J. The role of selenium in thyroid hormone metabolism and effects of selenium deficiency on thyroid hormone and iodine metabolism. Biol. Trace Elem. Res. 1992, 34, 321-325. [CrossRef]

271. Dennert, G.; Zwahlen, M.; Brinkman, M.; Vinceti, M.; Zeegers, M.P.A.; Horneber, M. Selenium for preventing cancer. Cochrane Database Syst. Rev. 2011, 29, CD005195.

272. Johansson, U.; Johnsson, F.; Joelsson, B.; Berglund, M.; Akesson, B. Selenium status in patients with liver cirrhosis and alcoholism. Br. J. Nutr. 1986, 55, 227-233. [CrossRef]

273. Avery, J.C.; Hoffmann, P.R. Selenium, Selenoproteins, and Immunity. Nutrients 2018, 10, 1203. [CrossRef]

274. Campa, A.; Shor-Posner, G.; Indacochea, F.; Zhang, G.; Lai, H.; Asthana, D.; Scott, G.B.; Baum, M.K. Mortality risk in selenium-deficient HIV-positive children. J. Acquir. Immune. Defic. Syndr. Hum. Retrovirol. 1999, 20, 508-513. [CrossRef]

275. Kupka, R.; Msamanga, G.; Spiegelman, D.; Morris, S.; Mugusi, F.; Hunter, D.; Fawzi, W. Selenium Status Is Associated with Accelerated HIV Disease Progression among HIV-1-Infected Pregnant Women in Tanzania. J. Nutr. 2004, 134, 2556-2560. [CrossRef]

276. Campa, A.; Martinez, S.S.; Baum, M.K. Selenium in HIV/AIDS. In Selenium: Its Molecular Biology and Role in Human Health; Hatfield, D.L., Schweizer, U., Tsuji, P.A., Gladyshev, V.N., Eds.; Springer International Publishing: Cham, Switzerland, 2016; pp. 333-342.

277. Look, M.P.; Rockstroh, J.K.; Rao, G.S.; Kreuzer, K.A.; Spengler, U.; Sauerbruch, T. Serum selenium versus lymphocyte subsets and markers of disease progression and inflammatory response in human immunodeficiency virus-1 infection. Biol. Trace Elem. Res. 1997, 56, 31-41. [CrossRef] [PubMed]

278. Jones, C.Y.; Tang, A.M.; Forrester, J.E.; Huang, J.; Hendricks, K.M.; Knox, T.A.; Spiegelman, D.; Semba, R.D.; Woods, M.N. Micronutrient Levels and HIV Disease Status in HIV-Infected Patients on Highly Active Antiretroviral Therapy in the Nutrition for Healthy Living Cohort. J. Acquir. Immune. Defic. Syndr. 2006, 43, 475-482. [CrossRef] [PubMed]

279. Kaiser, J.D.; Campa, A.M.; Ondercin, J.P.; Leoung, G.S.; Pless, R.F.; Baum, M.K. Micronutrient Supplementation Increases CD4 Count in HIV-Infected Individuals on Highly Active Antiretroviral Therapy: A Prospective, Double-Blinded, Placebo-Controlled Trial. J. Acquir. Immune. Defic. Syndr 2006, 42, 523-528. [CrossRef] [PubMed]

280. Hurwitz, B.E.; Klaus, J.R.; Llabre, M.M.; Gonzalez, A.; Lawrence, P.J.; Maher, K.J.; Greeson, J.M.; Baum, M.K.; Shor-Posner, G.; Skyler, J.S.; et al. Suppression of Human Immunodeficiency Virus Type 1 Viral Load With Selenium Supplementation: A Randomized Controlled Trial. Arch. Intern. Med. 2007, 167, 148-154. [CrossRef]

281. Kamwesiga, J.; Mutabazi, V.; Kayumba, J.; Tayari, J.-C.K.; Uwimbabazi, J.C.; Batanage, G.; Uwera, G.; Baziruwiha, M.; Ntizimira, C.; Murebwayire, A.; et al. Effect of selenium supplementation on CD4+ T-cell recovery, viral suppression and morbidity of HIV-infected patients in Rwanda: A randomized controlled trial. AIDS 2015, 29, 1045-1052. [CrossRef]

282. Hori, K.; Hatfield, D.; Maldarelli, F.; Lee, B.J.; Clouse, K.A. Selenium Supplementation Suppresses Tumor Necrosis Factor $\alpha$-Induced Human Immunodeficiency Virus Type 1 Replication in Vitro. AIDS Res. Hum. Retroviruses 1997, 13, 1325-1332. [CrossRef] 
283. Siegfried, N.; Irlam, J.H.; Visser, M.E.; Rollins, N.N. Micronutrient supplementation in pregnant women with HIV infection. Cochrane Database Syst. Rev. 2012, 14, CD009755. [CrossRef]

284. Grobler, L.; Nagpal, S.; Sudarsanam, T.D.; Sinclair, D. Nutritional supplements for people being treated for active tuberculosis. Cochrane Database Syst. Rev. 2016, 29, CD006086. [CrossRef]

285. Alim, I.; Caulfield, J.T.; Chen, Y.; Swarup, V.; Geschwind, D.H.; Ivanova, E.; Seravalli, J.; Ai, Y.; Sansing, L.H.; Ste.Marie, E.J.; et al. Selenium Drives a Transcriptional Adaptive Program to Block Ferroptosis and Treat Stroke. Cell 2019, 177, 1262-1279.e25. [CrossRef]

286. Tainer, J.A.; Getzoff, E.D.; Richardson, J.S.; Richardson, D.C. Structure and mechanism of copper, zinc superoxide dismutase. Nature 1983, 306, 284-287. [CrossRef]

287. Samanovic, M.I.; Ding, C.; Thiele, D.J.; Darwin, K.H. Copper in Microbial Pathogenesis: Meddling with the Metal. Cell Host Microbe. 2012, 11, 106-115. [CrossRef] [PubMed]

288. Besold, A.N.; Culbertson, E.M.; Culotta, V.C. The Yin and Yang of copper during infection. J. Biol. Inorg. Chem. 2016, 21, 137-144. [CrossRef] [PubMed]

289. German, N.; Lüthje, F.; Hao, X.; Rønn, R.; Rensing, C. Chapter Two-Microbial Virulence and Interactions With Metals. In Progress in Molecular Biology and Translational Science; San Francisco, M., San Francisco, B., Eds.; Academic Press: Cambridge, MA, USA, 2016; pp. 27-49.

290. Sprietsma, J.E. Cysteine, glutathione (GSH) and zinc and copper ions together are effective, natural, intracellular inhibitors of (AIDS) viruses. Med. Hypotheses 1999, 52, 529-538. [CrossRef] [PubMed]

291. Moreno, T.; Artacho, R.; Navarro, M.; Pérez, A.; Ruiz-López, M.D. Serum copper concentration in HIV-infection patients and relationships with other biochemical indices. Sci. Total Environ. 1998, 217, 21-26. [CrossRef]

292. Ren, Y.; Smith, A. Mechanism of Metallothionein Gene Regulation by Heme-Hemopexin: ROLES OF PROTEIN KINASE C, REACTIVE OXYGEN SPECIES, AND cis-ACTING ELEMENTS. J. Biol. Chem. 1995, 270, 23988-23995. [CrossRef] [PubMed]

293. DrÖGe, W.; Gross, A.; Hack, V.; Kinscherf, R.; Schykowski, M.; Bockstette, M.; Mihm, S.; Galter, D. Role of Cysteine and Glutathione in HIV Infection and Cancer Cachexia: Therapeutic Intervention with N-Acetylcysteine. In Advances in Pharmacology; Sies, H., Ed.; Academic Press: Cambridge, MA, USA.

294. Staal, F.J.T.; Ela, S.W.; Roederer, M.; Anderson, M.T.; Herzenberg, L.A.; Herzenberg, L.A. Glutathione deficiency and human immunodeficiency virus infection. Lancet 1992, 339, 909-912. [CrossRef]

295. Dröge, W.; Eck, H.P.; Mihm, S. HIV-induced cysteine deficiency and T-cell dysfunction-A rationale for treatment with $\mathrm{N}$-acetylcysteine. Immunol. Today 1992, 13, 211-214. [CrossRef]

296. Zhang, Z.Y.; Reardon, I.M.; Hui, J.O.; O'Connell, K.L.; Poorman, R.A.; Tomasselli, A.G.; Heinrikson, R.L. Zinc inhibition of renin and the protease from human immunodeficiency virus type 1. Biochemistry 1991, 30, 8717-8721. [CrossRef]

297. Karlström, A.R.; Levine, R.L. Copper inhibits the protease from human immunodeficiency virus 1 by both cysteine-dependent and cysteine-independent mechanisms. Proc. Natl. Acad. Sci. USA 1991, 88, 5552-5556. [CrossRef]

298. Miesel, R.; Mahmood, N.; Weser, U. Activity of Cu2Zn2 superoxide dismutase against the human immunodeficiency virus type 1. Redox Rep. 1995, 1, 99-103. [CrossRef]

299. Agrawal, L.; Louboutin, J.-P.; Strayer, D.S. Preventing HIV-1 tat-induced neuronal apoptosis using antioxidant enzymes: Mechanistic and therapeutic implications. Virology 2007, 363, 462-472. [CrossRef] [PubMed]

300. Agrawal, L.; Louboutin, J.P.; Reyes, B.A.S.; Van Bockstaele, E.J.; Strayer, D.S. Antioxidant enzyme gene delivery to protect from HIV-1 gp120-induced neuronal apoptosis. Gene Ther. 2006, 13, 1645-1656. [CrossRef] [PubMed]

301. Hodek, J.; Zajícová, V.; Lovětinská-Šlamborová, I.; Stibor, I.; Müllerová, J.; Weber, J. Protective hybrid coating containing silver, copper and zinc cations effective against human immunodeficiency virus and other enveloped viruses. BMC Microbiol. 2016, 16 (Suppl. 1), 56. [CrossRef] [PubMed]

302. Borkow, G.; Sidwell, R.W.; Smee, D.F.; Barnard, D.L.; Morrey, J.D.; Lara-Villegas, H.H.; Shemer-Avni, Y.; Gabbay, J. Neutralizing viruses in suspensions by copper oxide-based filters. Antimicrob. Agents Chemother. 2007, 51, 2605-2607. [CrossRef] [PubMed]

303. Borkow, G.; Lara, H.H.; Covington, C.Y.; Nyamathi, A.; Gabbay, J. Deactivation of human immunodeficiency virus type 1 in medium by copper oxide-containing filters. Antimicrob. Agents Chemother. 2008, 52, 518-525. [CrossRef] [PubMed] 
304. Borkow, G.; Covington, C.Y.; Gautam, B.; Anzala, O.; Oyugi, J.; Juma, M.; Abdullah, M.S. Prevention of Human Immunodeficiency Virus Breast milk Transmission with Copper Oxide: Proof-of-Concept Study. Breastfeed Med. 2011, 6, 165-170. [CrossRef] [PubMed]

305. Li, W.; Li, G.; Steiner, J.; Nath, A. Role of Tat Protein in HIV Neuropathogenesis. Neurotox Res. 2009, 16, 205-220. [CrossRef]

306. Ngwainmbi, J.; De, D.D.; Smith, T.H.; El-Hage, N.; Fitting, S.; Kang, M.; Dewey, W.L.; Hauser, K.F.; Akbarali, H.I. Effects of HIV-1 Tat on enteric neuropathogenesis. J. Neurosci. 2014, 34, 14243-14251. [CrossRef]

307. Sabatier, J.M.; Vives, E.; Mabrouk, K.; Benjouad, A.; Rochat, H.; Duval, A.; Hue, B.; Bahraoui, E. Evidence for neurotoxic activity of tat from human immunodeficiency virus type 1. J. Virol. 1991, 65, 961-967. [CrossRef]

308. Johnson, T.P.; Patel, K.; Johnson, K.R.; Maric, D.; Calabresi, P.A.; Hasbun, R.; Nath, A. Induction of IL-17 and nonclassical T-cell activation by HIV-Tat protein. Proc. Natl. Acad. Sci. USA 2013, 110, 13588-13593. [CrossRef]

309. Haughey, N.J.; Holden, C.P.; Nath, A.; Geiger, J.D. Involvement of Inositol 1,4,5-Trisphosphate-Regulated Stores of Intracellular Calcium in Calcium Dysregulation and Neuron Cell Death Caused by HIV-1 Protein Tat. J. Neurochem. 1999, 73, 1363-1374. [CrossRef] [PubMed]

310. Haughey, N.J.; Mattson, M.P. Calcium dysregulation and neuronal apoptosis by the HIV-1 proteins Tat and gp120. J. Acquir. Immune. Defic. Syndr. 2002, 31 (Suppl. 2), S55-61. [CrossRef] [PubMed]

311. Deme, P.; Rojas, C.; Slusher, B.S.; Rais, R.; Afghah, Z.; Geiger, J.D.; Haughey, N.J. Bioenergetic adaptations to HIV infection. Could modulation of energy substrate utilization improve brain health in people living with HIV-1? Exp. Neurol. 2020, 327, 113181. [CrossRef] [PubMed]

312. Tyagi, M.; Rusnati, M.; Presta, M.; Giacca, M. Internalization of HIV-1 Tat Requires Cell Surface Heparan Sulfate Proteoglycans. J. Biol. Chem. 2001, 276, 3254-3261. [CrossRef] [PubMed]

313. Ensoli, B.; Buonaguro, L.; Barillari, G.; Fiorelli, V.; Gendelman, R.; Morgan, R.; Wingfield, P.; Gallo, R. Release, uptake, and effects of extracellular human immunodeficiency virus type 1 Tat protein on cell growth and viral transactivation. J. Virol. 1993, 67, 277-287. [CrossRef] [PubMed]

314. Weihofen, W.A.; Liu, J.; Reutter, W.; Saenger, W.; Fan, H. Crystal Structures of HIV-1 Tat-derived Nonapeptides Tat-(1-9) and Trp2-Tat-(1-9) Bound to the Active Site of Dipeptidyl-peptidase IV (CD26). J. Biol. Chem. 2005, 280, 14911-14917. [CrossRef]

315. Khan, N.; Halcrow, P.W.; Lakpa, K.L.; Afghah, Z.; Miller, N.M.; Dowdy, S.F.; Geiger, J.D.; Chen, X. Two-pore channels regulate Tat endolysosome escape and Tat-mediated HIV-1 LTR transactivation. FASEB J. 2020, 34, 4147-4162. [CrossRef]

316. Khan, N.; Lakpa, K.L.; Halcrow, P.W.; Afghah, Z.; Miller, N.M.; Geiger, J.D.; Chen, X. BK channels regulate extracellular Tat-mediated HIV-1 LTR transactivation. Sci. Rep. 2019, 9, 12285. [CrossRef]

317. Khan, N.; Datta, G.; Geiger, J.D.; Chen, X. Apolipoprotein E isoform dependently affects Tat-mediated HIV-1 LTR transactivation. J. Neuroinflamm. 2018, 15, 91. [CrossRef]

318. Fan, Y.; He, J.J. HIV-1 Tat Promotes Lysosomal Exocytosis in Astrocytes and Contributes to Astrocyte-mediated Tat Neurotoxicity. J. Biol. Chem. 2016, 291, 22830-22840. [CrossRef]

319. Rahimian, P.; He, J.J. Exosome-associated release, uptake, and neurotoxicity of HIV-1 Tat protein. J. Neurovirol 2016, 22, 774-788. [CrossRef]

320. Hofman, F.; Wright, A.; Dohadwala, M.; Wong-Staal, F.; Walker, S. Exogenous tat protein activates human endothelial cells. Blood 1993, 82, 2774-2780. [CrossRef] [PubMed]

321. Westendorp, M.O.; Li-Weber, M.; Frank, R.W.; Krammer, P.H. Human immunodeficiency virus type 1 Tat upregulates interleukin-2 secretion in activated T cells. J. Virol. 1994, 68, 4177-4185. [CrossRef] [PubMed]

322. Huang, L.; Li, C.J.; Pardee, A.B. Human immunodeficiency virus type 1 TAT protein activates B lymphocytes. Biochem. Biophys. Res. Commun. 1997, 237, 461-464. [CrossRef] [PubMed]

323. Gibellini, D.; Bassini, A.; Pierpaoli, S.; Bertolaso, L.; Milani, D.; Capitani, S.; La Placa, M.; Zauli, G. Extracellular HIV-1 Tat protein induces the rapid Ser133 phosphorylation and activation of CREB transcription factor in both Jurkat lymphoblastoid T cells and primary peripheral blood mononuclear cells. J. Immunol. 1998, 160, 3891-3898. [PubMed]

324. Kumar, A.; Manna, S.K.; Dhawan, S.; Aggarwal, B.B. HIV-Tat protein activates c-Jun N-terminal kinase and activator protein-1. J. Immunol. 1998, 161, 776-781. [PubMed] 
325. Ott, M.; Lovett, J.L.; Mueller, L.; Verdin, E. Superinduction of IL-8 in T cells by HIV-1 Tat protein is mediated through NF-кB factors. J. Immunol. 1998, 160, 2872-2880.

326. Hui, L.; Chen, X.; Haughey, N.J.; Geiger, J.D. Role of endolysosomes in HIV-1 Tat-induced neurotoxicity. ASN Neuro 2012, 4, 243-252. [CrossRef]

327. El-Hage, N.; Rodriguez, M.; Dever, S.M.; Masvekar, R.R.; Gewirtz, D.A.; Shacka, J.J. HIV-1 and Morphine Regulation of Autophagy in Microglia: Limited Interactions in the Context of HIV-1 Infection and Opioid Abuse. J. Virol. 2015, 89, 1024-1035. [CrossRef]

328. Frankel, A.D.; Chen, L.; Cotter, R.J.; Pabo, C.O. Dimerization of the tat protein from human immunodeficiency virus: A cysteine-rich peptide mimics the normal metal-linked dimer interface. Proc. Natl. Acad. Sci. USA 1988, 85, 6297-6300. [CrossRef]

329. Pierleoni, R.; Menotta, M.; Antonelli, A.; Sfara, C.; Serafini, G.; Dominici, S.; Laguardia, M.E.; Salis, A.; Damonte, G.; Banci, L.; et al. Effect of the redox state on HIV-1 tat protein multimerization and cell internalization and trafficking. Mol. Cell Biochem. 2010, 345, 105-118. [CrossRef] [PubMed]

330. Zecca, L.; Youdim, M.B.H.; Riederer, P.; Connor, J.R.; Crichton, R.R. Iron, brain ageing and neurodegenerative disorders. Nat. Rev. Neurosci. 2004, 5, 863-873. [CrossRef] [PubMed]

331. Ward, R.J.; Zucca, F.A.; Duyn, J.H.; Crichton, R.R.; Zecca, L. The role of iron in brain ageing and neurodegenerative disorders. Lancet Neurol. 2014, 13, 1045-1060. [CrossRef]

332. Liu, J.-L.; Fan, Y.-G.; Yang, Z.-S.; Wang, Z.-Y.; Guo, C. Iron and Alzheimer's Disease: From Pathogenesis to Therapeutic Implications. Front. Neurosci. 2018, 12, 632. [CrossRef]

333. Drakesmith, H.; Prentice, A.M. Hepcidin and the Iron-Infection Axis. Science 2012, 338, 768-772. [CrossRef]

(C) 2020 by the authors. Licensee MDPI, Basel, Switzerland. This article is an open access article distributed under the terms and conditions of the Creative Commons Attribution (CC BY) license (http://creativecommons.org/licenses/by/4.0/). 